\title{
EVALUATING THE VIABILITY OF INTENSIFICATION AROUND THREE SUBURBAN GO STATIONS
}

By

Nicola Sharp

BSc, University of Victoria, 2011

A Major Research Paper

presented to Ryerson University

in partial fulfillment of the requirements for the degree of

Master of Planning

in

Urban Development

Toronto, Ontario, Canada, 2018

(C) Nicola Sharp, 2018 


\section{Author's Declaration for Electronic Submission of a MRP}

I hereby declare that I am the sole author of this MRP. This is a true copy of the MRP, including any required final revisions.

I authorize Ryerson University to lend this MRP to other institutions or individuals for the purpose of scholarly research.

I further authorize Ryerson University to reproduce this MRP by photocopying or by other means, in total or in part, at the request of other institutions or individuals for the purpose of scholarly research.

I understand that my MRP may be made electronically available to the public. 
Evaluating the Viability of Intensification Around Three Suburban GO Stations

(C) Nicola Sharp, 2018

Master of Planning

in

Urban Development

Ryerson University

\begin{abstract}
$\underline{\text { Abstract }}$
The updated Growth Plan for the Greater Golden Horseshoe (2017) requires all GO rail station areas to achieve a minimum density of 150 residents and jobs combined per hectare. Intensification is unlikely to occur without intentional policy and partnerships to encourage development. Mid-rise buildings, the typical residential form needed to meet the intensification target, are often challenging to develop in suburban areas. Similarly, employment intensification can be challenging to achieve without incentives for office location. Policy, politics and market viability all impact intensification. Changes are needed at the provincial, regional and local level to encourage development. Regulatory changes like zoning, partnerships between Metrolinx and developers and/or financial incentives, such as reduced development charges, should be explored to encourage intensification. Suburban GO rail station intensification is an opportunity to achieve multiple policy goals, such as the creation of walkable, affordable communities that increase housing choice.
\end{abstract}

An article on transit station intensification in the Greater Toronto and Hamilton Area, used the keywords: transit oriented development, intensification, Greater Toronto and Hamilton Area 


\section{$\underline{\text { Acknowledgements }}$}

I would like to thank my supervisor, Professor David Amborski, and my second reader, Mark

Conway, for their guidance. My friends and family have provided support throughout this program, particularly Blair. Thank you all. 


\section{Table of Contents}

Author's Declaration for Electronic Submission of a MRP ..................................................................ii

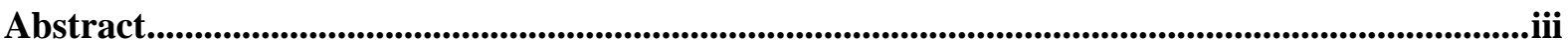

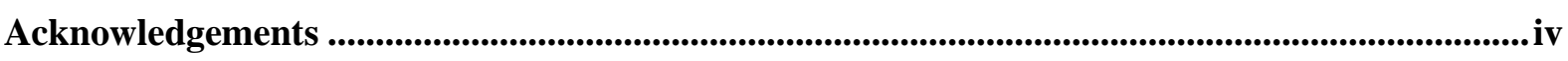

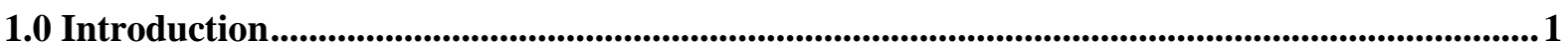

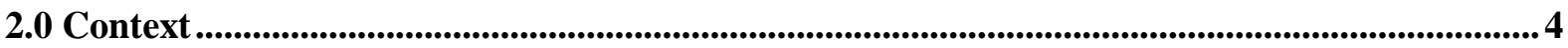

2.1 Regional Context............................................................................................................................... 4

2.2. Land Use and Transportation Planning in the GTHA.............................................................6 6

2.3 Land Development in the GTHA ................................................................................................. 7

2.4 GO Rail Network and Station Planning ........................................................................................... 10

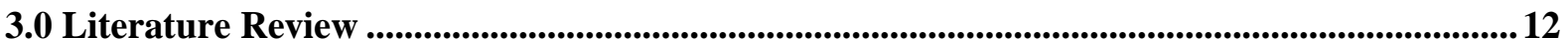

3.1 Land Use and Transportation Policy .............................................................................................12

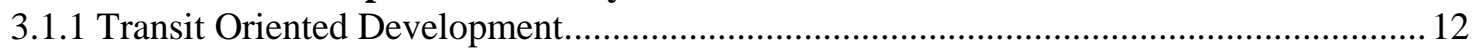

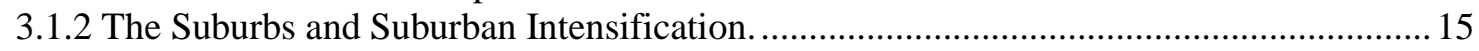

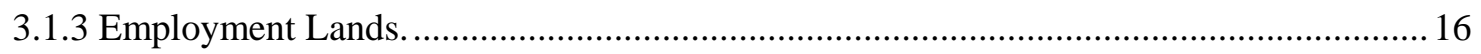

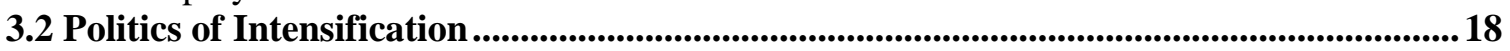

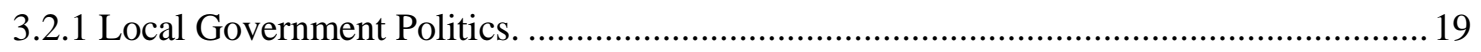

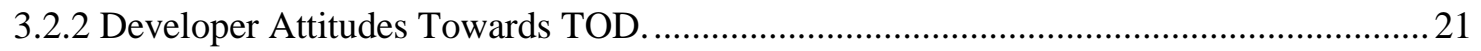

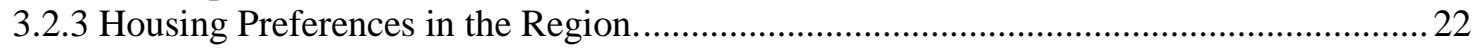

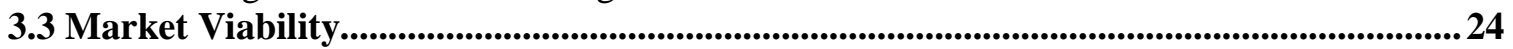

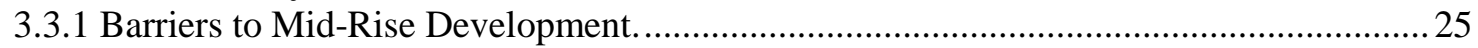

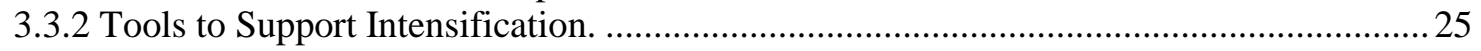

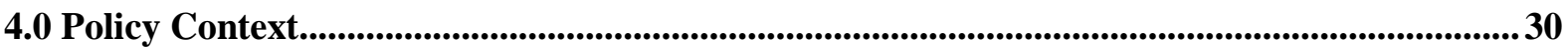

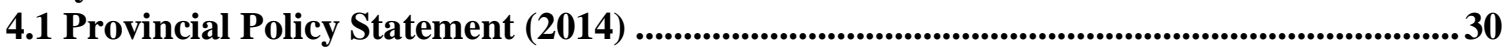

4.2 Growth Plan for the Greater Golden Horseshoe (2017) ......................................................30

4.3 Building Better Communities and Conserving Watersheds Act (2017)................................31

4.4 2041 Regional Transportation Plan (2018).........................................................................................32

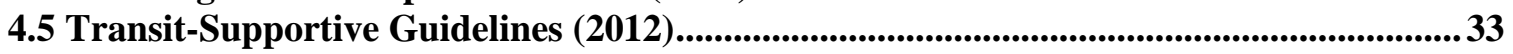

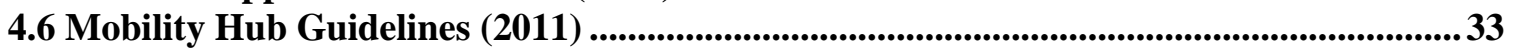

4.7 Station Area Parking...........................................................................................................................34

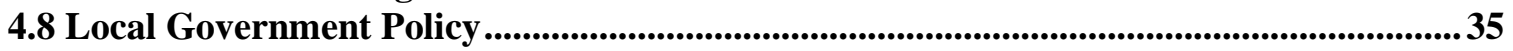

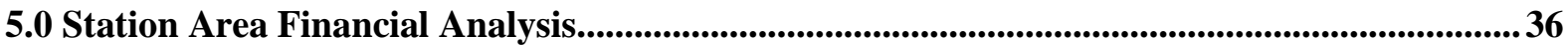

5.1 Residual Land Value Assumptions .......................................................................................38

5.2 Appleby Station Analysis ..........................................................................................................................39

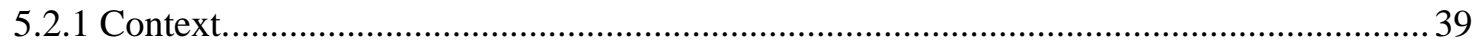

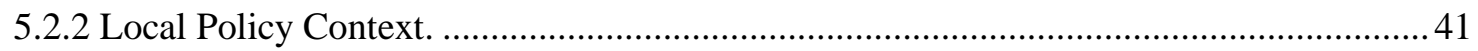

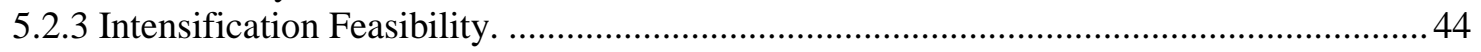

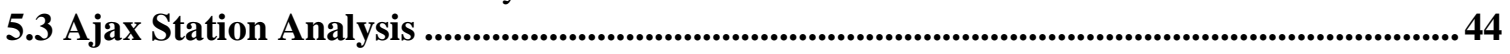

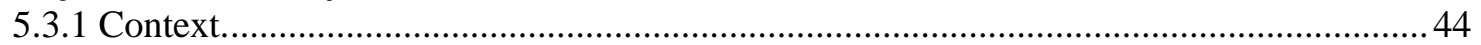

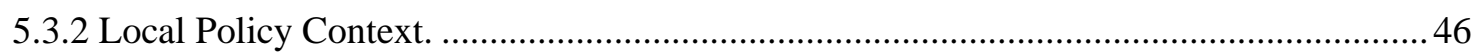

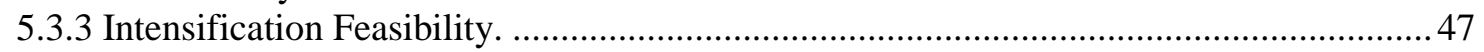

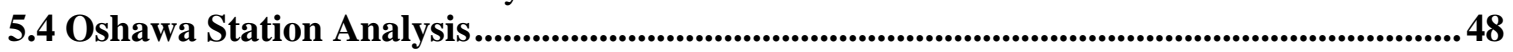

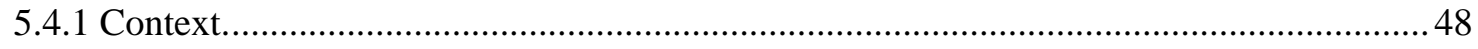

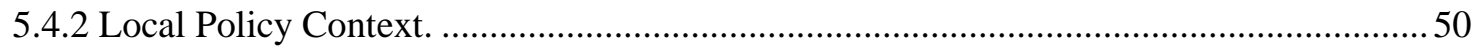

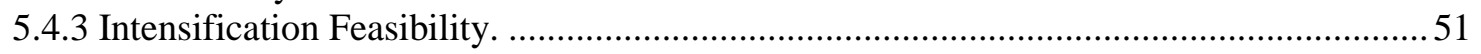

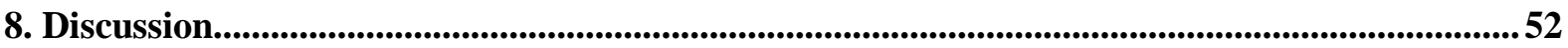

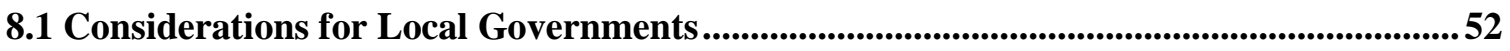

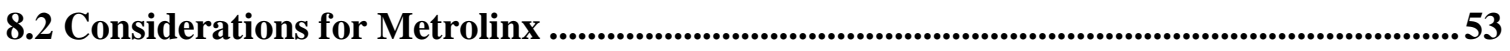

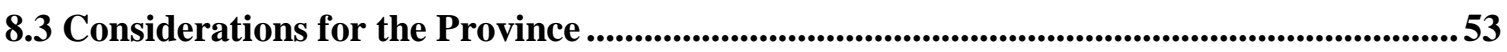

8.4 Recommendations.............................................................................................................................54 


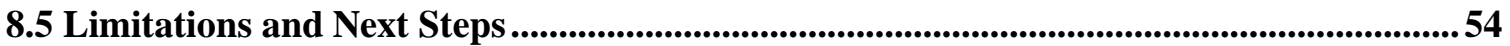

9.0 Conclusion .................................................................................................................................................56

Appendix 1: Residual Land Value Analysis Results..............................................................................57

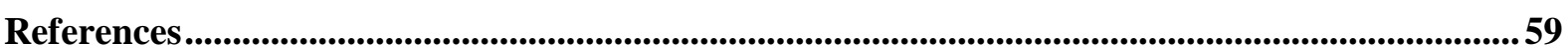




\section{List of Tables}

Table 1. Comparison of net residential densities by housing type (Neptis, 2008)

Table 2. Jobs, land area and density of Mississauga employment districts in 2004 (Nelson, 2004 and cited in Neptis, 2008)

Table 3. Index of residential land-use regulation in the Greater Toronto and Hamilton Area (Green,

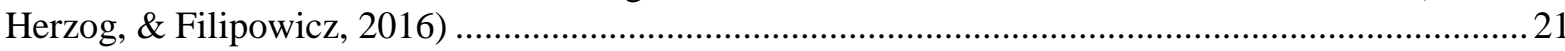

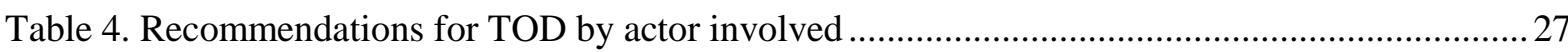

Table 5. Suburban station area characteristics of three stations (NBLC, 2016; Census, 2016)............ 37

Table 6. Station area characteristics for Appleby, Ajax and Oshawa related to housing density (NBLC, 2016)

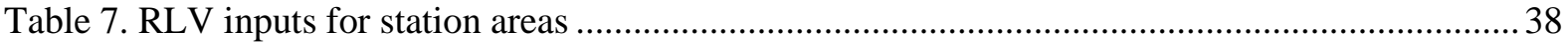

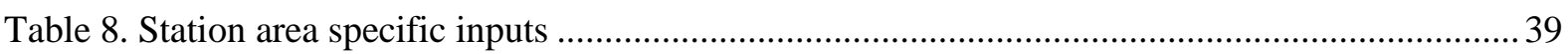

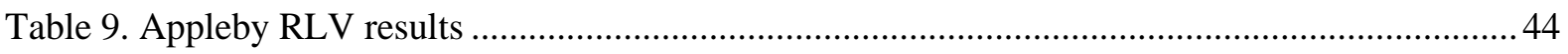

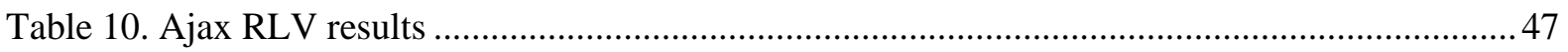

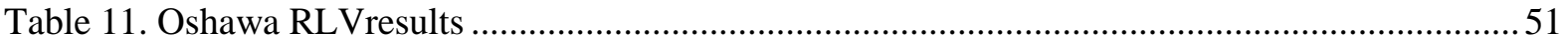

Table 12. Residual land value analysis for a theoretical eight story condominium building in Appleby,

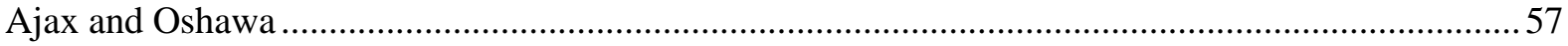

Table 13. Summary of development costs by station .....................................................................5 


\section{List of Figures}

Figure 1. GO rail station density (City Building Institute, 2016) 2

Figure 2. Greater Golden Horseshoe and the Greater Toronto and Hamilton Area (Metrolinx, 2016c) 5

Figure 3. Concept for Growth Plan density targets (Ministry of Municipal Affairs and Housing,

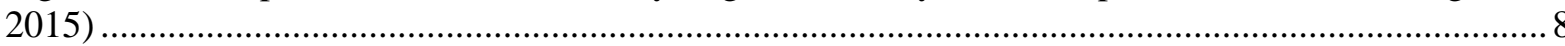

Figure 4. Existing and In Delivery Regional Rail and Rapid Transit Projects (Metrolinx, 2018)....... 10

Figure 5. Current (2016) and targeted (2031) mode used to access GO rail stations (Metrolinx, 2017)

Figure 6. The Transit Adjacent Development (TAD) and Transit Oriented Development (TOD)

spectrum (Renne, 2009)

Figure 7. Interactions between government, households and property developers in the urban economy

Figure 8. Share of housing types by age group in the GTHA, 2011 (Metrolinx, 2016b).

Figure 9. GO rail parking supply and ridership growth (GO Rail Cordon Counts and 2031 GO Rail

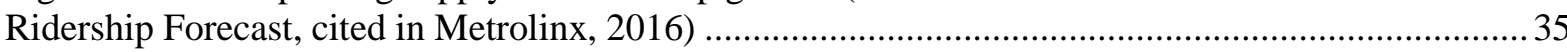

Figure 10. Location of Appleby, Ajax and Oshawa stations. 36

Figure 11. Number of completed units in the GTA within 800 metres of a GO station, 2000-2015 (NBLC, 2016) 38

Figure 12. Location of the Appleby GO rail station in Burlington .....................................................40

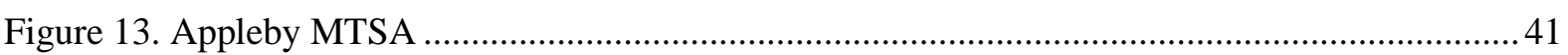

Figure 14. Preferred land use concept for the Appleby mobility hub (City of Burlington, 2017) .........43

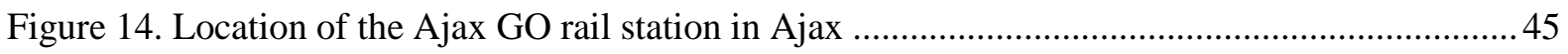

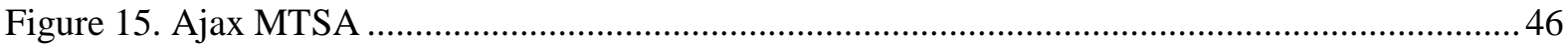

Figure 16. Location of the Oshawa GO rail station in Oshawa ..........................................................49

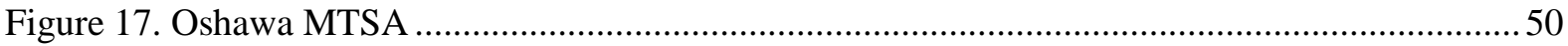




\section{List of Appendices}

Appendix 1: Residual Land Value Analysis Results 


\section{$\underline{1.0 \text { Introduction }}$}

Two plans were recently approved that impact land use and transportation planning in the Greater Toronto and Hamilton Area (GTHA): the Regional Transportation Plan (RTP) (March 8, 2018) and the Growth Plan for the Greater Golden Horseshoe (May 18, 2017), also known as the Growth Plan. The updated Growth Plan (2017) contains intensification targets for major transit station areas (MTSA), such as GO rail stations. Policy 2.2.4.3 for Transit Corridors and Station Areas states that: 3. Major transit station areas on priority transit corridors or subway lines will be planned for a minimum density target of:

c) 150 residents and jobs combined per hectare for those that are served by the GO Transit rail network

(Growth Plan, 2017, p. 17)

The RTP has a complementary action (priority action 4.3) to intensify MTSAs (Metrolinx, 2018).

Policies in these plans address the need to coordinate growth planning and transportation infrastructure investment.

Unless an alternative target is approved, the Growth Plan (2017) intensification target is uniform across all GO rail stations. GO rail stations vary across the region, from Union station in Downtown Toronto to stations like King City surrounded by a low density residential neighbourhood and greenfield lands. The City Building Institute (2016) found that only two stations, Hamilton and Union, meet the Growth Plan (2017) density target of 150 people and jobs per hectare (Figure 1). The report from the Coordinated Review Advisory Panel (2017) found that about 80 percent of the region's GO rail stations have a density that is less than 50 residents and jobs combined per hectare. 
Figure 1. GO rail station density (City Building Institute, 2016)

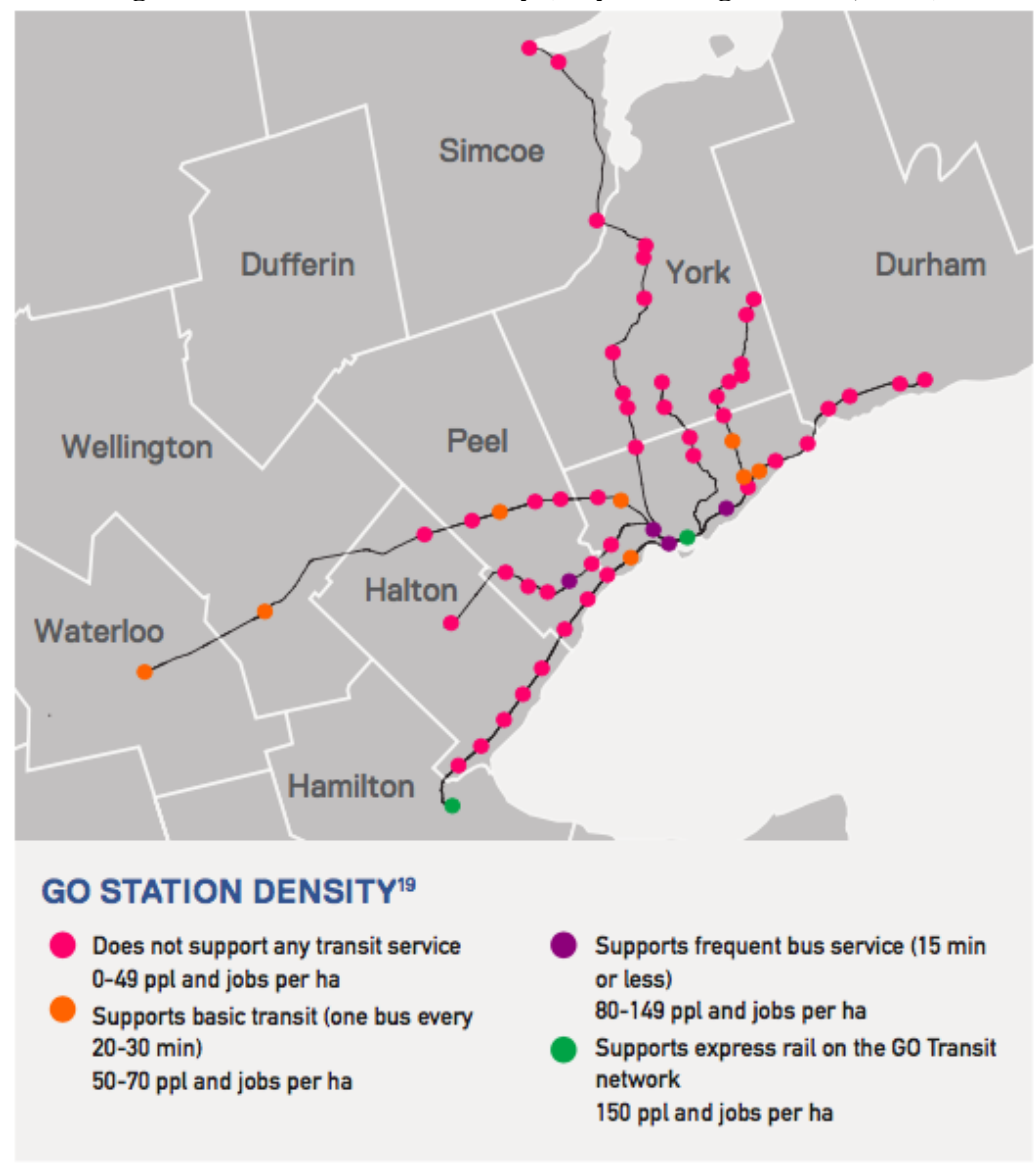

When exploring the intensification of suburban stations, it is important to consider that there are different opportunities and constraints compared to urban stations. The GO Rail Station Access Plan (2016) defines suburban transit nodes as:

Destinations with auto-oriented urban form, good land availability for development, and a growing market for mixed use development. They include stations located within and on the edge of suburban areas. Some are Gateway Suburban Transit Nodes, which also serve a larger rural catchment area.

When considering the future of suburbs, a number of typologies are used to describe different types of suburban areas and their attributes. The classic suburb is described as: "low density, automobileoriented, predominantly residential, and outside the central city" (Moos \& Walter-Joseph, 2017, p.108). A transit oriented suburb is described as "medium to high-density, predominantly residential, some retail, higher transit use, some walkable areas, outside the historic city centre" (Moos \& WalterJoseph, 2017, p.108). The focus of this report is to understand how classic suburbs can intensify into transit oriented suburbs around GO rail stations. 
This paper explores whether the Growth Plan (2017) intensification target is achievable in suburban areas. Suburban stations have a different policy, political and market context than urban centres. These three categories - policy, politics and market viability - are frequently used in transportation and suburban intensification literature to discuss the opportunities and challenges of intensification (Grant, 2009; Sotomayor, 2013; Cervero, et al., 2002). Intensification is unlikely to occur by market forces alone (Boarnet \& Crane, 1998); however, the increased service provided as part of the regional express rail (RER) will likely increase the desirability of living near GO rail stations. RER will increase service along several GO rail lines to two-way, 15-minute service. Even with changing attitudes towards transit oriented development in the suburbs, policy changes will likely be needed to achieve intensification goals around suburban GO rail stations. A literature review, policy review and residual land value analysis for sample mid-rise residential developments in Burlington, Ajax and Oshawa are used to understand suburban station intensification. The outcome of this research is a set of recommendations that governments should consider implementing to support the achievement of the station area intensification targets. 


\section{$\underline{2.0 \text { Context }}$}

\subsection{Regional Context}

The Greater Golden Horseshoe (GGH) in southern Ontario stretches from the Niagara Region to the County of Northumberland and north to the City of Orillia, shown in Figure 2. This is the geography of the Growth Plan (2017), along with other growth management plans like the Greenbelt Plan (2017). In 2016, the population of the GGH was 9,245,438, a quarter of the Canadian population (Statistics Canada, 2016). The GGH is expected to grow to about 13.5 million people by 2041, and jobs are expected to grow from 4.5 million to 6.3 million (Advisory Panel for the Coordinated Review, 2015). This growth has not been distributed evenly across or within municipalities. For example, Downtown Toronto and three employment megazones - the Airport, Tor-York East and TorYork West - experienced a significant portion of the employment growth between 2001 and 2011 (Neptis, 2015b).

The Growth Plan (2017) and previous iterations of the Growth Plan have sought to concentrate population growth in mixed-use, built up and walkable communities. Despite this aim, growth in the GGH has largely been in suburban areas (Advisory Panel for the Coordinated Review, 2015). The updated Growth Plan (2017) seeks to strengthen intensification policy, such as transit station area intensification. 
Figure 2. The Greater Golden Horseshoe and the Greater Toronto and Hamilton Area (Metrolinx, 2016c)

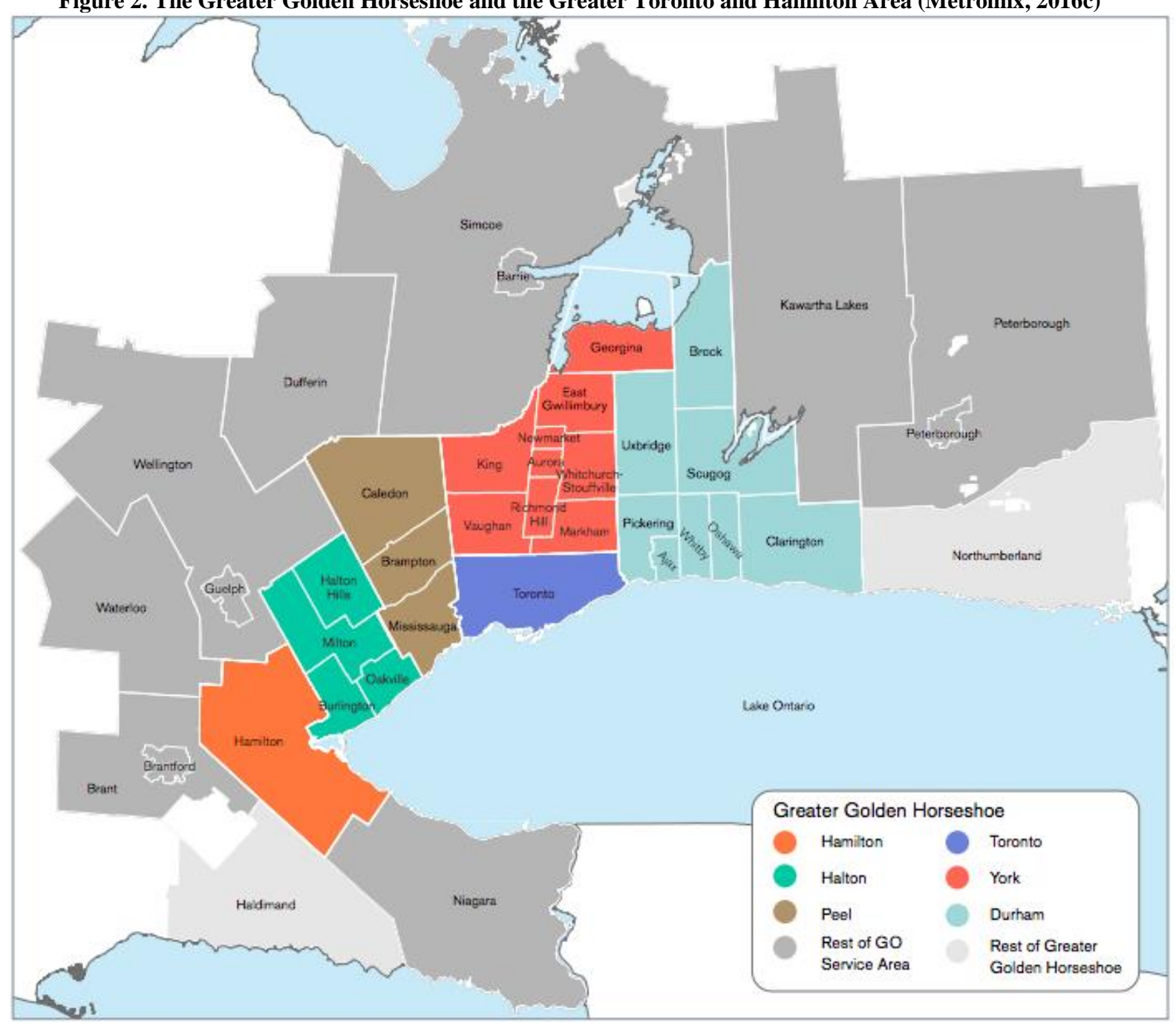

The Greater Toronto and Hamilton Area (GTHA) is in the GGH, shown in Figure 2. The GTHA spans from Hamilton to Clarington and north to Lake Simcoe. Metrolinx is the regional transportation agency for the GTHA and the Regional Transportation Plan (2018) outlines the transportation planning vision for this area. In 2016, the population of the GTHA was 6,954,433 (City of Toronto, 2017). This is almost a fifth of the population of Canada (City of Toronto, 2017). From 2011 to 2016, the population increased by 5.8 percent (City of Toronto, 2017). Individual municipalities grew at different rates, from 0.2 percent to 30.5 percent (City of Toronto, 2017). Milton, King, WhitchurchStouffville, Brampton and Caledon grew the fastest (City of Toronto, 2017). 
From 2001 to 2011, 14 percent of new residents in the GTHA were accommodated in intensification areas (Neptis, 2015a). The majority of growth occurred in suburban areas (Neptis, 2015a). Despite the concentration of growth in greenfield areas, sprawl in the GTHA has been declining overall. ${ }^{1}$ The Growth Plan (2017), Greenbelt Plan (2017) and other provincial plans limit growth on greenfield land. The supply of land in the GGH is constrained and the majority of growth must be accommodated in already built-up areas. From 2001 to 2011, only 18 percent of new GTHA residents located in areas near frequent transit ${ }^{2}$, of which ten percent were located near GO stations (Neptis, 2015a). Transit-rich suburban areas are an underutilized opportunity for intensification. Station intensification can increase housing diversity and offer alternatives to vehicle dependency, achieving multiple policy priorities.

\subsection{Land Use and Transportation Planning in the GTHA}

In Ontario, land use policy is organized as a hierarchy, with provincial policy guiding regional and municipal policy. Two important provincial policies are the Provincial Policy Statement (PPS) (2014) and Growth Plan (2017), both of which are summarized in Section 4, Policy Context. There is no provincial transportation plan. Some high-level transportation policies are integrated into the PPS (2014) and Growth Plan (2017), such as prioritizing growth near transit. More specific transportation policies are found in local transit plans and the RTP (2018). The Growth Plan (2017) station area intensification targets are an example of land use and transportation planning alignment. Although provincial and regional plans provide some direction for planning around stations, implementation is the responsibility of local municipalities.

Local governments are categorized as lower-, upper- or single-tier municipalities. Lower-tier municipal Official Plans must comply with upper-tier Official Plans. For example, the Town of Ajax

\footnotetext{
${ }^{1}$ The Neptis Foundation (2015a) describes the occurrence of sprawl as when urban expansion is greater than the increase in population. Urban expansion was determined was using satellite imagery to identify urbanized areas (areas with development) and nonurban areas (such as a farm).

${ }^{2}$ Neptis (2015a) defines areas near frequent transit network as places within 500 metres of 15 -minute transit service, like bus or streetcar lines. GO rail does not currently have 15-minute service. Once RER is implemented, frequent service will be available on some lines.
} 
Official Plan must conform with the Region of Durham Official Plan. The province has limited enforcement tools to ensure that municipalities are complying with provincial policy. Municipalities vary on how encouraging they are of intensification, and there is also variation in transportation investments. Some municipalities, like Toronto, have their own transportation agency. Others, like Ajax, are served by a regional transportation agency (Durham Region Transit).

Metrolinx was created in 2006 to coordinate transportation planning in the GTHA. In 2008, the first RTP was adopted, the Big Move. Metrolinx's role is primarily to coordinate transportation planning in the region, with an additional role to provide service. In 2009, Metrolinx merged with GO Transit, which provides regional bus and rail service (Metrolinx, 2018). Metrolinx works with local governments to determine transportation investment priorities. The RTP (2018) outlines these investments and operational priorities.

\subsection{Land Development in the GTHA}

The patterns of land development in the GTHA are impacted by changes in demographics, increased congestion, and the market. Specific to residential development, medium and high density development tends to be impacted by housing affordability, demographics, transit access, demand for investment in the rental market and other quality of life factors (e.g. access to amenities) (NBLC, 2016). These considerations impact the feasibility of suburban station intensification.

There has been a lot of development around many Toronto transit stations, but this has not been seen to the same degree outside of Toronto (NBLC, 2016). Transit improvements that result in service that is more frequent, more reliable and low cost increases the demand for housing near stations (NBLC, 2016). Higher-order transit service can result in a 10 percent increase in residential properties (NBLC, 2016). This increase in residential value can help to make land development feasible. Without pricing premiums around transit stations, suburban development can be hard to support (NBLC, 2016). The housing forms that are needed to achieve the Growth Plan (2017) intensification target are often a new product in suburban markets and therefore viewed as a risky investment.

In a suburban setting, a higher density will not necessarily achieve a higher return. If consumers do not want to buy condominiums in a mid- or high-rise apartment, the sales timing could be long, and a 
project may not sell the required number of units before construction. To understand viability, the built form needed to achieve Growth Plan (2017) targets should be understood. For residential development, the built form that achieves the intensification target is predominately mid-rise buildings, as shown in the 150 people and jobs combined per hectare concept below (Figure 3) (Ministry of Municipal Affairs and Housing, 2015).

Figure 3. Concept for Growth Plan density targets (Ministry of Municipal Affairs and Housing, 2015)

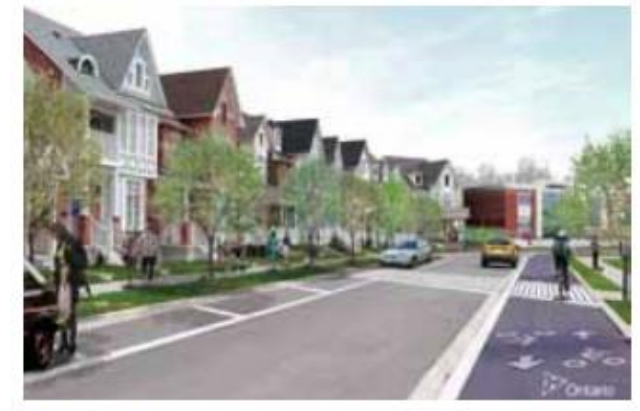

Density of approximately 50 people and jobs combined per hectare

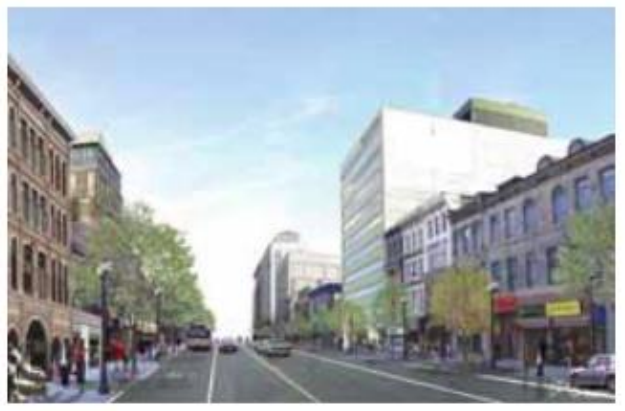

Density of approximately 200 people and jobs combined per hectare

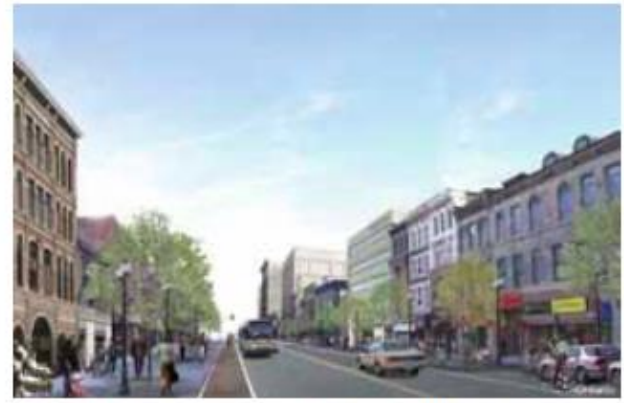

Density of approximately 150 people and jobs combined per hectare

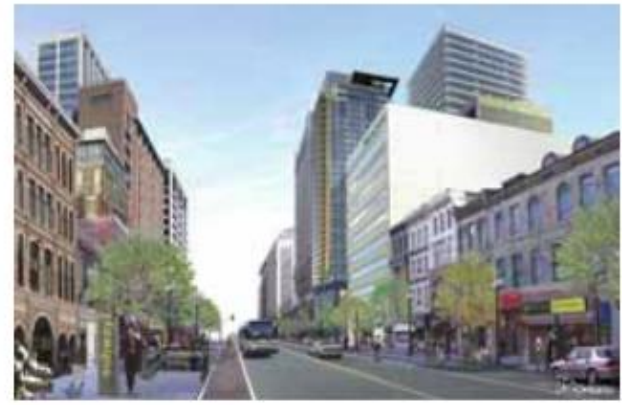

Density of approximately 400 people and jobs combined per hectare

The Neptis Foundation completed a regional study of greenfield development that outlined similar housing forms and density (Neptis, 2008). A comparison of five studies found that 150 people per hectare is generally achieved through stacked townhouses and apartments, at least 54 units per hectare, shown in Table $1 .^{3}$

\footnotetext{
${ }^{3}$ In The GTHA there are generally 2.75 people in each household (Statistics Canada, 2016). A limitation of this generalization is that household size tends to decrease as unit sizes become smaller.
} 
Table 1. Comparison of net residential densities by housing type (Neptis, 2008)

\begin{tabular}{lrrrrr}
$\begin{array}{l}\text { Net residential density, } \\
\text { units per hectare }\end{array}$ & $\begin{array}{r}\text { Diamond } \\
(\mathbf{1 9 7 6 )}\end{array}$ & $\begin{array}{r}\text { MHO } \\
\text { (1993:18) }\end{array}$ & $\begin{array}{r}\text { CMHC } \\
\text { (n.d.) }\end{array}$ & $\begin{array}{r}\text { BLGDG } \\
\text { (1995) }\end{array}$ & $\begin{array}{r}\text { UDAS-NSW } \\
\text { (1998) }\end{array}$ \\
\hline Single Detached & 20 & $20-36$ & $20-27$ & $19-45$ & $11-16$ \\
\hline Semi-Detached & 35 & $33-43$ & 30 & $24-70$ & $11-21$ \\
\hline Townhouse & 47 & $54-59$ & $37-44$ & $55-98$ & $35-56$ \\
\hline Stacked Townhouse & $77-86$ & $35-57$ & $49-62$ & $62-319$ & $69-131$ \\
\hline Apartment & $160-175$ & $86-161$ & $74-198$ & $100-273$ & $64-141$ \\
\hline
\end{tabular}

Employment intensification looks different than residential intensification. Employment density varies depending on whether an area contains manufacturing or office uses (Neptis, 2008). A 2005 study of employment densities in Mississauga calculated the densities in different employment districts. None of the districts profiled achieve 150 jobs per hectare, with the airport area coming the closest with 137 jobs to hectare (Neptis, 2008). Also referenced in the Shaping the Toronto Region (2008) report was a 2004 study that summarized employment density by use (Table 2).

Table 2. Jobs, land area and density of Mississauga employment districts in 2004 (Nelson, 2004 and cited in Neptis,

\begin{tabular}{|c|c|c|c|c|c|}
\hline Employment Land-Use Category & $\begin{array}{r}20 \\
\text { Gross floor- } \\
\text { space per } \\
\text { employee }\left(\mathrm{ft}^{2}\right)\end{array}$ & $\begin{array}{l}\text { 8) } \\
\text { Gross floor- } \\
\text { space per } \\
\text { employee }\left(m^{2}\right)\end{array}$ & FAR & $\begin{array}{r}\text { Jobs / } \\
\text { site acre }\end{array}$ & $\begin{array}{l}\text { Jobs / gross } \\
\text { site hectare }\end{array}$ \\
\hline \multicolumn{6}{|l|}{ Industrial } \\
\hline Construction & 288 & 27 & .19 & 29 & 71 \\
\hline Manufacturing & 609 & 57 & .23 & 16 & 41 \\
\hline $\begin{array}{l}\text { Transportation, Communications, } \\
\text { and Utilities }\end{array}$ & 277 & 26 & .19 & 30 & 74 \\
\hline Wholesale Trade & 698 & 65 & .26 & 16 & 40 \\
\hline \multicolumn{6}{|l|}{ Office } \\
\hline General Office (surface parking) & 350 & 33 & .25 & 31 & 77 \\
\hline Office Park (surface parking) & 350 & 33 & .42 & 52 & 129 \\
\hline $\begin{array}{l}\text { Suburban Multilevel (structured or } \\
\text { underground parking) }\end{array}$ & 336 & 31 & .84 & 109 & 269 \\
\hline
\end{tabular}

Source: Nelson (2004:47).

As shown in this Table 2, the Growth Plan (2017) density target would be achieved through office uses. However, since the Growth Plan's (2017) policy seeks mixed-use intensification around MTSAs, the land uses would likely be a combination of offices and apartments. A diversity of residential forms could be considered - such as townhouses, mid-rise buildings and towers - that balance to the minimum target of 150 residents and jobs per hectare. 


\subsection{GO Rail Network and Station Planning}

Metrolinx operates rail service throughout the GTHA, shown in Figure 4. Five of the seven lines are part of the regional express rail (RER) initiative that is increasing service to all day, 15-minute service. Stations that will have increased service are on six lines: the Barrie GO line, Kitchener GO line, Lakeshore East GO line, Lakeshore West GO line and the Union Station Rail Corridor.

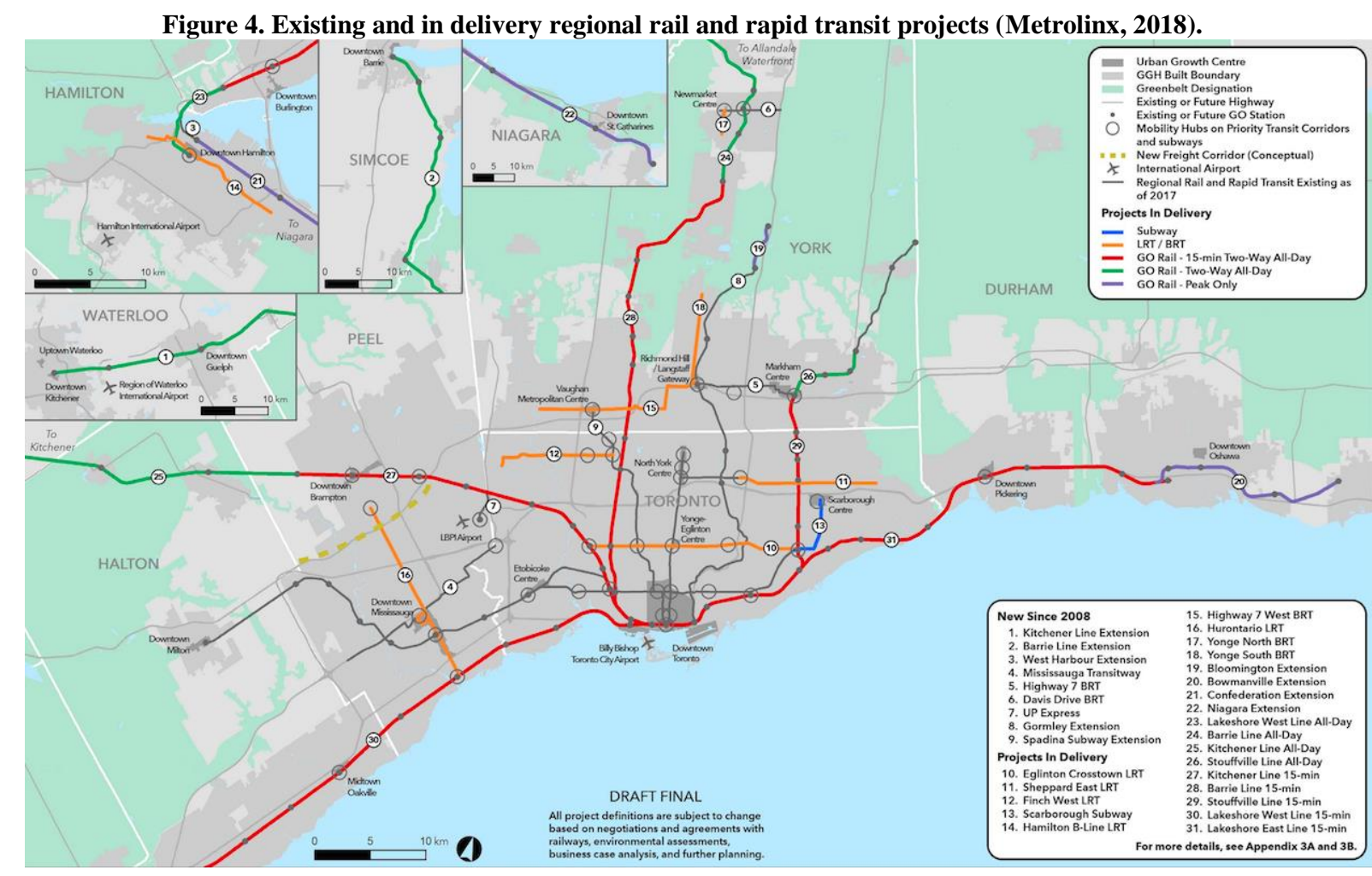

As part of the RER planning process, station assessments were undertaken to understand how stations fit into the broader transportation network, as well as the potential for intensification. The $G O$ Regional Express Rail Initial Business Case (2015) included a list of factors for consideration that were:

- Factors that affect mode share.

- Patterns of development and change in patronage at a station.

- Bus and other service development.

- Changing car ownership and general traffic congestion growth that might affect access modes.

- Policy development promoting, for example, cycle access, bus or walk modes.

- Lack of parking, pattern of bus service access, etc.

- Pattern/geographic spread of land-use changes created by GO RER, which may be to tighten or extend catchment areas. 
Although the aim of station planning is to increase active modes of transportation and encourage intensification, vehicles are the primary transportation mode for arriving to stations. Metrolinx aims to reduce the number of people who drive and park from 62 percent to 36 percent by 2031, as shown in Figure 5 (Metrolinx, 2017). Metrolinx intends to prioritize station access investments based on a transportation hierarchy that favours pedestrians, followed by transit, cycling, pick up/drop off, carpool and parking (Metrolinx, 2016a). Active modes of transportation will be encouraged by building complete streets, increasing intersection density, implementing bike share, and improving transit connections to stations (Metrolinx, 2016a). Improvements that change built form and local transit service require the cooperation of Metrolinx, local transit agencies, local municipalities and land owners.

Figure 5. Current (2016) and targeted (2031) mode used to access GO rail stations (Metrolinx, 2017)

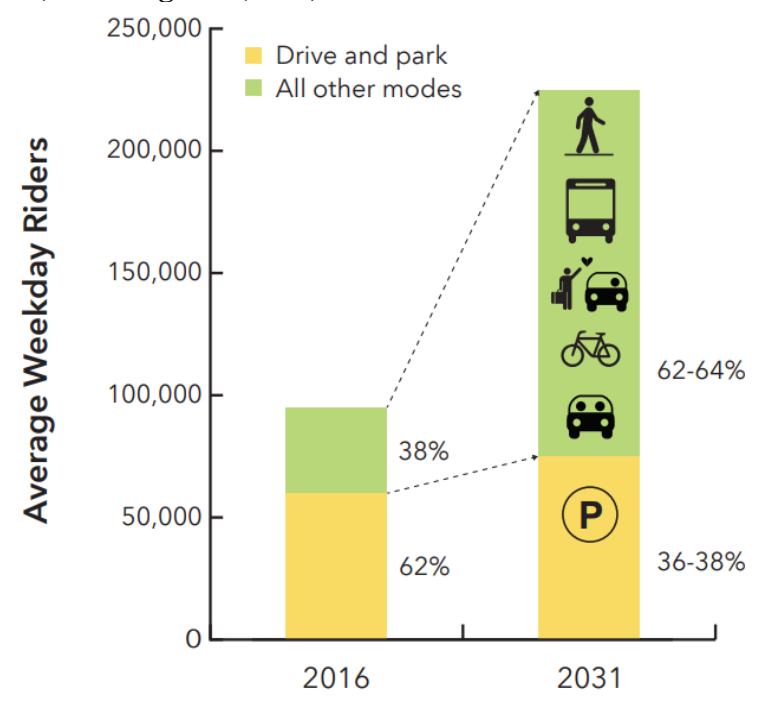

As a result of the Growth Plan (2017) and an increasing focus on intensification throughout the region, it is appropriate to explore how station areas in low density, vehicle dependent suburban areas will evolve. It is anticipated that there will be an increase in housing market demand around stations that are served by RER (NBLC, 2016). Suburban stations are challenged by preferences for groundoriented housing and station areas that are unattractive (NBLC, 2016). Yet, even with these challenges, station areas are a regional opportunity for achieving intensification and transportation goals. 


\section{$\underline{\text { 3.0 Literature Review }}$}

\subsection{Land Use and Transportation Policy}

Cervero (2002) highlights the need for government involvement to achieve land intensification goals around transit stations. Historically, there was an assumption that intensification would naturally occur (Boarnet and Crane, 1998). The more nuanced view is that there are a combination of factors. Calthorpe (1993) stated that "our patterns of growth are as much a result of public policy and subsidies, outdated regulations, environmental forces, technology and simple inertia as they are a result of the invisible hand of Adam Smith" (p. 10). Thoughtful land use and transportation policy is one of the factors needed to support intensification goals (Boarnet and Crane, 1998). The following sections summarize the policy considerations that influence the coordination of transportation and land use planning. Some themes that fall under the policy topic are: transit oriented development, suburban intensification and employment lands.

\subsubsection{Transit Oriented Development.}

There are many descriptions of transit oriented development (TOD). Cervero (2002) describes TOD as compact development located near a transit station that promotes active transportation, and is designed with a focus on public space. Sohoni, et al. (2017) describe it succinctly as "reconnecting transportation and land use" (p. 3225). The principles of TOD are:

- Organize growth on a regional level to be compact and transit-supportive;

- Place commercial, housing, jobs, parks, and civic uses within walking distance of transit stops;

- Create pedestrian-friendly street networks which directly connect local destinations;

- $\quad$ Provide a mix of housing types, densities, and costs;

- Preserve sensitive habitat, riparian zones, and high quality open space;

- Make public spaces the focus of building orientation and neighbourhood activity; and

- Encourage infill and redevelopment along transit corridors within existing neighbourhoods.

(Calthorpe, 1993, p. 43)

The principles of TOD are similar to the principles of smart growth, neo-traditional planning, and new urbanism (Calthorpe, 1993). TOD can also be referred to as a transit village, transit-focused development and transit station community, among other terms (Dunphy, et al., 2005). Transit joint development, a slightly different term, refers to development that is directly integrated with a transit 
station (Hess and Lombardi, 2004). For example, this could be a station below ground with an office tower above. TOD should not be confused with transit adjacent development (TAD), which is development near transit stations without easy access to the station (Renne, 2009). Many of the existing areas around GO rail stations could be considered TAD. Figure 6 summarized some of the key attributes of TAD and TOD. TOD is not achieved simply by developing near transit. Rather, it is a comprehensive planning process to build a complete community that promotes transit ridership.

Figure 6. The transit adjacent development (TAD) and transit oriented development (TOD) spectrum (Renne, 2009).

\begin{tabular}{|l|l|}
\hline \multicolumn{2}{|c|}{ Characteristics of Station Precinct: } \\
- Suburban street pattern & - Grid street pattern \\
- Low densities & - High densities \\
- Dominance of surface parking & - Mostly underground or structured \\
- Limited or no pedestrian access & parking \\
- Simited or no bicycle access/parking & - Pedestrian-focused design \\
- Ingle-family homes & - Bicycle access/parking \\
- Segregated land uses & - Multi-family homes \\
- Gas stations, car dealerships, drive- & Office and retail land uses, \\
thru stores and other auto-focused & - Vertically along main streets \\
land uses & land uses \\
\hline
\end{tabular}

The Growth Plan's (2017) MTSA policies are aligned with the TOD literature, such as a focal area of a 10-minute walk (or 500 metres), mixed uses and walkable community design (Hess and Lombardi, 2004). A residential density of about 97 residents per hectare is recommended for TOD, lower than the Growth Plan (2017) target of 150 residents and jobs per hectare (Hess and Lombardi, 2004).

A number of actors are involved in TOD: transit agencies, municipalities, regional government and developers (Hess and Lombardi, 2004). Although there are many actors involved in TOD, it often falls to one actor to be the primary facilitator (Hess and Lombardi, 2004). Bernick and Cervero (1997) suggest that the lead should be the transit agency. Although the transit agency may be a natural lead in the United States, Metrolinx's powers to participate in redevelopment are limited by the Metrolinx Act (2006). Metrolinx's purpose if to deliver transit, and land development is not within the scope of their mandate (2006). Local governments may have a much greater role to play in land development the GTHA. Metrolinx's involvement in land development may evolve, and there are some examples of 
station redevelopment plans, like the Port Credit GO Station joint development project and EglintonCrosstown stations (Metrolinx, 2017; Wickens, 2017).

Intensification around transit stations is important because it limits sprawl, reduces greenhouse gases (GHG) and decreases traffic congestion. A California Department of Transportation study summarized the list of benefits as:

- Provides mobility choices,

- Increases public safety,

- Increases transit ridership,

- Reduces rates of vehicle miles traveled,

- Increases households' disposable income,

- Reduces air pollution and energy consumption rates,

- Helps conserve resource lands and open space,

- Plays a role in economic development,

- Decreases infrastructure costs, and

- Contributes to more affordable housing

(Hess and Lombardi, 2004, Page 2)

In addition to the benefits of reducing vehicle use, intensification around stations is advantageous because it is an opportunity to increase the supply of housing and locate jobs near transit. Increasing the supply of housing helps to improve housing affordability, which is especially important given the limited supply of land in the Greater Toronto Area (Amborski, 2016). Development near transit stations also improves the affordability of housing because access to transit can decrease transportation costs for households, which increases the budget available for housing or other goods (Canadian Centre for Economic Analysis, 2016). Although much of the TOD literature espouses the benefits of TOD, some studies do question whether TOD benefits are always realized (Hess and Lombardi, 2004). For example, transit ridership may not increase as much as expected (Hess and Lombardi, 2004).

Many suburban areas originally developed in the mid-nineteenth century because of streetcar and rail lines (Clapson, 2003). A transit accessible suburb is not a new concept, yet suburban development moved away from a transit focus as vehicle travel became more affordable, efficient and comfortable (Clapson, 2003). The Growth Plan (2017) now looks to reconnect vehicle dependent suburban areas to transit networks. Intensification around existing infrastructure is one of these opportunities. 


\subsubsection{The Suburbs and Suburban Intensification.}

Understanding how intensification in the suburbs occurs involves understanding of what the suburbs are, why the suburbs exist and how suburban and urban areas are different. Suburban areas are often synonymous with sprawl, which is frequently described as "unplanned, scattered, low-density, automobile-dependent development at the urban periphery" (Bruegmann, 2006, p.2). Amongst the many definitions of the suburbs and sprawl, there is no universally agreed upon definition (Bruegmann, 2006; Moos \& Mendez, 2017). For example, different types of areas are often grouped together, like older suburban neighbourhoods and new greenfield development, or unplanned and planned neighbourhoods (Clapson, 2003). Some definitions categorize suburban and urban areas based on characteristics like built form and transportation networks; whereas other definitions take a more qualitative perspective based on the difference in experiences of an urban and suburban area (Moos \& Mendez, 2017). Moos and Mendez (2017) categorize suburban areas based on:

1. Residence in a single detached house;

2. Homeownership as a type of housing tenure; and

3. Private automobile use as a mode of commute.

Using this definition of a suburban area, Moos and Mendez (2017) mapped suburban areas in major North American cities, including the Greater Toronto Area (GTA). According to the mapping project, 41 percent of the population in the GTA, a population of about five million, lived in the most suburban type of neighbourhood, a place that exhibited the three characteristics outlined above. About a quarter of people (24\%) lived in areas that did not have suburban characteristics.

The connotation of the suburb is often negative, especially with the increased awareness of health and sustainability concerns, as well as the popularity of smart growth (Bruegmann, 2006). Understanding suburban areas requires not just understanding the consequences of low density and vehicle dependent development, but also why this type of development occurs. Bruegmann (2006) argues that the common assumptions for the cause of sprawl - automobile use, government policies

\footnotetext{
${ }^{4}$ The mapping did not include the entire GTHA. The boundaries were Ajax on the east and Oakville on the west.
} 
and racism - are inadequate. Increasing wealth and the democratization of society are argued to be factors that caused sprawl (Bruegmann, 2006; Clapson, 2003). Increased wealth means that households have more privacy, mobility and choice, resulting in an ability to live farther from the city centre in larger homes (Bruegmann, 2006). Suburban neighborhoods offer privacy that is very expensive to purchase in a city (Bruegmann, 2006). ${ }^{5}$

Despite arguments that suburban development is a result of choice and economic growth, the consequences and costs of suburban development cannot be ignored. The costs of suburban neighbourhoods, like pollution, environmental degradation, and poor physical health, are costs borne by society (Calthorpe, 1993). For this reason, the future of suburban neighbourhoods is an important consideration for everyone.

\subsubsection{Employment Lands.}

Many of the GO rail stations are located in or near employment lands. Uses on employment lands can vary from high density offices to low density manufacturing and distribution. Building dense, mixed-use communities around transit stations involves the consideration of employment lands conversion. Protecting employment lands is a priority of both the Provincial Policy Statement (2014) and Growth Plan (2017). Growth Plan (2017) policies that promote mixed-use station area intensification conflict with policies that state that employment lands should be protected. The Growth Plan (2017) has a conversion policy to guide changes in employment lands. Municipalities can only redesignate land during the municipal comprehensive review (Coordinated Review Advisory Panel, 2017). The Growth Plan (2017) employment policy 2.2.5 states that:

9. The conversion of lands within employment areas or prime employment areas to non-employment uses may be permitted only through a municipal comprehensive review where it is demonstrated that:

a) there is a need for the conversion;

\footnotetext{
${ }^{5}$ Although there is continued demand for suburban living, there is also a rise in the desirability of urban condominium living, in part because of intentional advertising from developers (Lehrer, Keil, \& Kipfer, 2010). The increase in luxury condominiums provides an opportunity to have both access to amenities and privacy. In the case of condominiums, privacy is provided by vertical separation and private security, rather than horizontal between detached homes. An example of changing preferences is that luxury condominium sales increased by 85 percent in 2017 (RE/MAX, 2017).
} 
b) the lands are not required over the horizon of this Plan for the employment purposes for which they are designated;

c) the municipality will maintain sufficient employment lands to accommodate forecasted employment growth to the horizon o this Plan;

d) the proposed uses would not adversely affect the overall viability of the employment area or prime employment area or the achievement of the minimum intensification and density targets in this Plan, as well as the other policies of this Plan; and

e) there are existing or planned infrastructure and public service facilities to accommodate the proposed uses.

The Growth Plan (2017) recognizes that employment lands vary, with some being places for office and others being heavy industrial areas. Since there are a variety of types of uses in employment lands, the Growth Plan (2017) has politics specifically for prime employment lands, which are traditional industrial uses that are in strategic locations (such as near a highway) and are important for economic growth. Examples are: manufacturing, warehousing, and logistics, and appropriate associated uses and ancillary facilities (Growth Plan, 2017). The Growth Plan (2017) encourages intensification of employment lands. Locating office uses near major transit station areas is a Growth Plan (2017) priority (policies 2.2.5.2 and 2.2.4.9). Employment lands conversion to housing is not recommended because this can leave employment lands fragmented and unviable for continued employment uses (Coordinated Review Advisory Panel, 2017). Arguments that support employment lands conversion are that demand for traditional industrial uses has reduced as jobs have shifted from manufacturing to knowledge-based and service sectors (Coordinated Review Advisory Panel, 2017). For example, between 2001 and 2015, 200,000 manufacturing jobs were lost in the GGH (Neptis, 2015b).

The challenge in introducing residential and/or office uses into industrial areas, which many of the employment lands are, is that land speculation can compromise the viability of existing uses, like manufacturing (Lester, Kaza, and Kirk, 2013). Lester, Kaza, and Kirk (2013) found that regional housing demand, gentrification and access to transit infrastructure intensify land speculation. Industrial lands are important because they provide high quality jobs with low education requirements and low-cost land for start-up companies (Lester, Kaza, and Kirk, 2013). When considering the conversion of industrial lands or changing employment areas from industrial to office spaces, it is 
important to recognize both the direct and indirect benefits employment lands provide, as well as the benefits and costs of conversion.

\subsection{Politics of Intensification}

From community support, attitudes of local councillors and developer interest, the politics of intensification impact development potential. Peng, $\mathrm{Li}$, and Choi (2017) summarize the interactions between government, households and property developers in Figure 7. The motivations of these actors are different. For example, governments are often concerned about the public good; although what that public good objective is may vary by government. Households make location choices based on affordability and preferences, and land developers are concerned about making a profit on an investment, with some additional motivation based on reputation.

Figure 7. Interactions between government, households and property developers in the urban economy (Peng, $\mathrm{Li}$, and Choi, 2017)

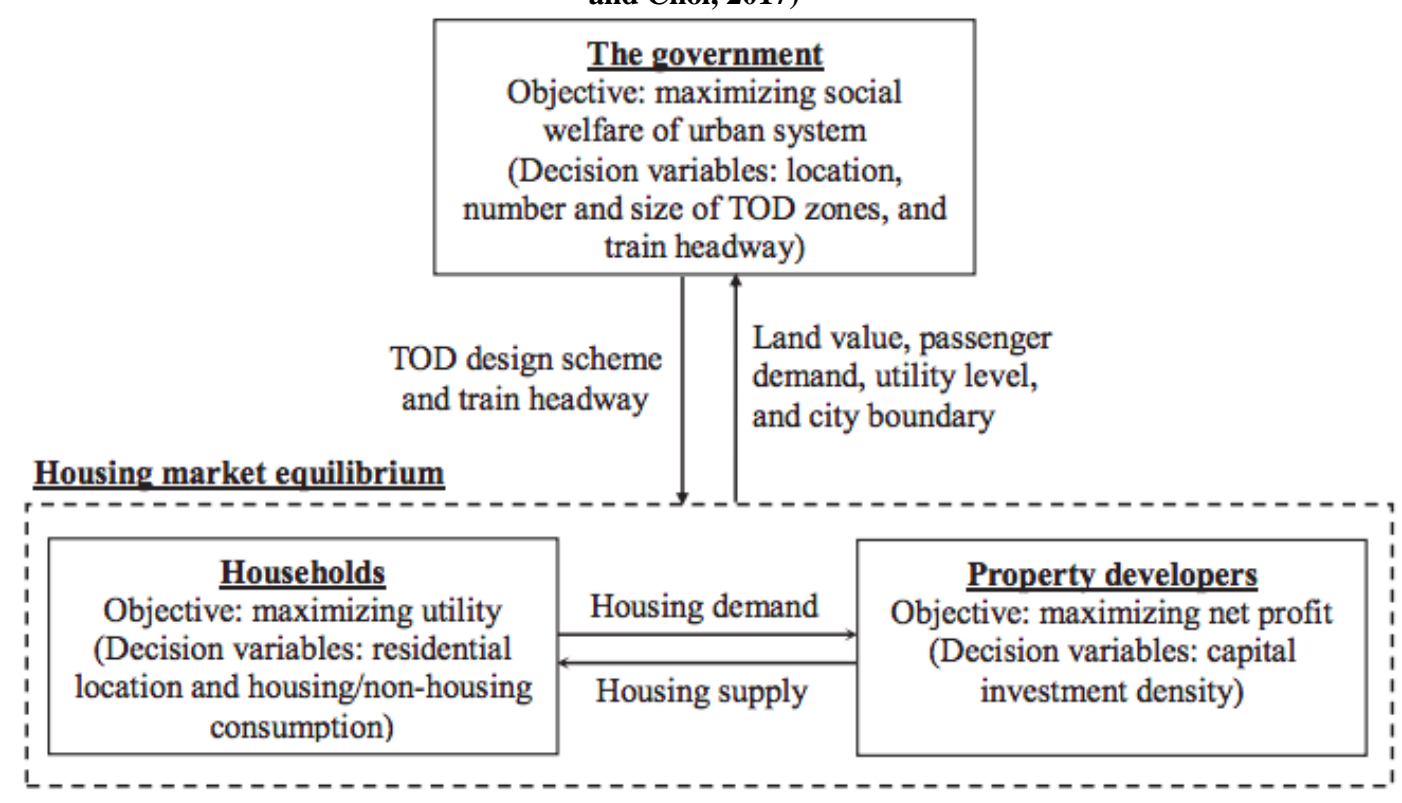

An actor not included in Figure 7 are transit agencies. Dunphy, et al. (2005) observed that transit agencies are often busy managing day-to-day transit operations and do not have the capacity to also oversee station redevelopment. Other actors to consider are public interest groups that may advocate for active transportation, housing, and/or sustainability (Dunphy, et al., 2005). Conversely, public interest groups may also oppose intensification because of concerns of changing neighbourhood character or increased congestion. The following sections summarize considerations for government, developers and households. 


\subsubsection{Local Government Politics.}

Although many GTHA municipalities are supportive of intensification around transit, there is tension when policy is regionally adopted and locally implemented. Boarnet and Crane (1998) observed that transit authorities are focused on the success of the rail system; whereas municipalities are focused on community needs that may relate to a single station, rather than the network. Financial motivations, particularly tax revenue, were seen as a key difference between municipal and transit authority attitudes in Southern California (Boarnet and Crane, 1998). Local governments in Southern California often preferred commercial development around stations because commercial development was associated with lower costs (due to lower service demand) and higher revenue for the local government (due to higher tax rates). Transit authorities wanted higher intensity residential uses because residential uses increased transit ridership (Boarnet and Crane, 1998). There is a trade-off between tax revenue and ridership.

Another consideration is that local governments often want to maintain the character of an area (Grant, 2009). Intensification is not always in keeping with low density forms that are traditionally found in suburban communities. Community members can amplify these concerns. Politicians are influenced both by constituent attitudes and election cycles (Grant, 2009; Searle \& Filion, 2011). Existing residents frequently want their neighbourhoods to remain stable and unchanged (Searle \& Filion, 2011; Filion \& McSpurren, 2007). In addition to the influence of residents, Grant (2009) found that political connections between councillors and developers (like councillors having a background in the development industry), and the support (or lack thereof) given to staff impacted the success of intensification policies.

Often intensification in suburban areas requires incentives. Municipalities face a tradeoff when considering tools that may support intensification. For example, tax increment financing grants and municipal fee reduction are techniques suggested to promote development (Metrolinx, 2011). The downside of these policies is that the municipality will carry, at least in the short to medium term, the cost of a loss in property tax and the cost of infrastructure upgrades (like servicing). No change, rather than significant intensification, is often seen as more desirable (Searle \& Filion, 2011). 
The Live Where You Go (2012) report outlined several policy options for encouraging location efficient housing that were politically feasible or unfeasible. The findings were based on a survey of industry professionals. Making development charges transparent to homebuyers, unbundling parking costs from the purchase or rental of a unit, and aligning development decisions and transportation planning were viewed as politically feasible. Several other options were perceived to be unfeasible, like the provision of rebates or tax credits for location-efficient housing when purchasing housing. ${ }^{6}$ The other policies that were not viewed as politically feasible were: basing development charges on the true cost of growth related infrastructure, reforming the property tax system ${ }^{7}$, and fast tracking location-efficient development applications. Lastly, some policies were considered only slightly politically feasible. Those were: development of a Transportation Planning Policy Statement, linking Metrolinx funding to pre-zoning stations, pre-zoning transit hubs, reforming property tax for parking lots, and including location costs in mortgage risk assessments (Pembina Institute, 2012).

Municipal fees and charges can impact the viability of development. In 2016, the Fraser Institute released a survey completed by developers and homebuilders (a total of 93 respondents) on the cost and time involved in housing development. The council and community index, a measure of attitudes towards development, found that community members and Council were not a deterrent to development in Burlington. Survey respondents stated that they would not pursue development in Ajax and Oshawa because of concerns about community reception (Green, Herzog, \& Filipowicz, 2016). Burlington is viewed as the most efficient municipality to develop in with regulations that impose the least amount of costs on housing. The more negative the aggregate index is, shown in

\footnotetext{
${ }^{6}$ An example provided is the TD Canada Trust Green Mortgage, which includes a 1\% discount on a five year fixed-rate interest rate for energy efficient improvements. In the case of location efficient, the discount would be provided based on where the home is located (Pembina Institute, 2012).

${ }^{7}$ The study suggested that development in areas without good transit access to should penalized with higher property taxes (and other taxes like development charges) to account for the negative impact non-location efficient housing has. Examples are:

- $\quad$ "Allow two-rate property tax system where buildings and improvements are taxed at lower rate than land

- Allow differential tax rates for single-family vs. multifamily dwellings

- Incorporate location efficiency metrics into tax assessment

- Lower property tax and earmark for shared essentials; increase user fees.

- Implement charges or rebates based on location efficiency criteria"

(Pembina Institute, 2012, p. 18)
} 
Table 3, the better development is perceived in each municipality (Green, Herzog, \& Filipowicz, 2016). Ajax is viewed as one of the hardest municipalities to build in, only King Township is more challenging. Table 3 provide a summary of the Fraser Institute report for the three stations that are used as a case study for financial analysis, found in Section 5, Station Area Financial Analysis.

Table 3. Index of residential land-use regulation in the Greater Toronto and Hamilton Area (Green, Herzog, \& Filipowicz, 2016)

\begin{tabular}{|l|c|c|c|c|c|c|}
\hline & $\begin{array}{c}\text { Approval } \\
\text { Timelines } \\
\text { (months) }\end{array}$ & $\begin{array}{c}\text { Council and } \\
\text { Community } \\
\text { Index }\end{array}$ & $\begin{array}{c}\text { Municipal } \\
\text { Cost } \\
\text { and Fees }\end{array}$ & $\begin{array}{c}\text { Rezoning } \\
\text { Prevalence }\end{array}$ & $\begin{array}{c}\text { Timeline } \\
\text { Uncertainty }\end{array}$ & $\begin{array}{c}\text { Aggregate } \\
\text { Index }\end{array}$ \\
\hline Burlington & 14.4 & 2.6 & $\$ 32,500$ & $50 \%$ & 2.8 & -2.71 \\
\hline Oshawa & 19.0 & 2.6 & $\$ 50,357$ & $60 \%$ & 3.0 & -0.05 \\
\hline Ajax & 19.7 & 3.2 & $\$ 54,318$ & $61 \%$ & 3.1 & 1.38 \\
\hline Average & 18.2 & 2.9 & $\$ 48,034$ & $62 \%$ & 2.9 & \\
\hline
\end{tabular}

The Fraser Institute survey is not a perfect gauge for understanding barriers to development because it is research conducted for advocacy purposes. Respondents have an incentive to state that development is challenging in hopes that fee and application timing will be reduced. Nonetheless, it is a tool for comparing the development process across different municipalities.

\subsubsection{Developer Attitudes Towards TOD.}

The motivations of developers can vary when it comes to TOD. Some studies found that developers can be hesitant to build TOD and smart growth communities, whereas other research found a willingness. Consumer demand has a large impact on the motivation of developers, and consumer preferences vary depending on the local market. Increased household interest in TOD can trigger increased interest from developers because developers want to build what is being demanded (Grant, 2009). One study found that demand for walkable neighbourhoods can increase developer interest (Guthrie \& Fan, 2016). Changing consumer preferences can be slow in a suburban market (Grant,

\footnotetext{
${ }^{8}$ The index is ranked as: [1] encourages development; [2] not a deterrent to development; [3] mild deterrent to development; [4] Strong deterrent to development; and [5] would not pursue development due to this factor (Green, Herzog, \& Filipowicz, 2016).

${ }^{9}$ As above.
} 
2009). For example, a case study in Markham found that the desire for parking and privacy were in conflict with smart growth objectives (Grant, 2009). Developers interviewed as part of the Markham study stated that land policy will not solve land development issues when there is simply not consumer demand (Grant, 2009).

There is diversity in the types and motivations of developers; however, amongst all types of developers there is a common aim to build a profitable development (Peiser \& Hamilton, 2012). Connected to profitability, is the impact of risk and uncertainty on investment decisions. Emerging markets are often viewed as a risky investment. Cervero et al. (2004) found that risk, such as whether TOD infrastructure is built, and product precedents (like recent residential development) impact the desirability of TOD development. There are a number of other factors that indirectly impact profit, like local policy. Developing Around Transit (2005), an Urban Land Institute publication, found that the key considerations for whether developers choose to build TOD are municipal policy, application approvals and market conditions. A recent newspaper article found that TOD was viewed positively by local developers and TOD was an emerging intensification opportunity in the GTHA (Lornic, 2017, November 12).

\subsubsection{Housing Preferences in the Region.}

Demand for housing depends on household preferences and housing supply. People modify their housing choices based on ability to pay and tradeoffs, for example a longer commute for a larger house. After reviewing several GTA surveys and housing start data, Clayton (2017) found that homebuyers continue to prefer ground-related homes, millennials being no exception. Outside of Toronto, there was an even higher demand for ground-related homes, especially single-detached homes. The Toronto Real Estate Board Market Year in Review and Outlook Report (2017) published the results of a November 2016 GTA survey that found that 48 percent of likely homebuyers wanted to purchase a detached home. The proportion of likely homebuyers interested in purchasing an apartment increased from 18 percent in 2015 to 28 percent in 2016 (Toronto Real Estate Board, 2017). The rise in interest for apartment units may be because of preference changes; however, this may also be a substitution effect given the price and availability of ground-related housing, or a 
change in preferences in favor of more livable communities. The challenge with preference surveys is that people will often respond based on aspirations, rather than reality. With finite greenfield land and a growing population, it is essential to increase densities. It is not possible to house everyone in a ground-oriented housing form. It is also not desirable. As previously discussed, suburban development has negative health, financial and environmental impacts for society.

There are indications that livability is becoming an increasingly important factor when making housing choices. The Toronto Board of Trade (BOT) survey (2017) found that young professionals (18 to 39 years) rank their commute to work as the most important location consideration. Amenities and cost of living are the next most important factors. The results of the BOT survey are similar to a $\mathrm{RBC} / \mathrm{Pembina}$ Institute report (2014) that found that 81 percent of respondents wanted to live in a walkable area with amenities near to rapid transit. ${ }^{10}$ TOD provides an opportunity to live in a walkable neighbourhood with transit options and access to amenities (Cervero, et al., 2002). Cervero, et al. (2002) found that residents around TOD are often young and childless or older and downsizing. Similar to TOD location preferences, there are also demographic trends associated with housing forms. Figure 8 shows that apartments are most popular with young people and regain popularity as people age. Housing uptake follows lifestyle trends. Families with children often prefer larger units that are ground-related (Metrolinx, 2016b). The timing for housing upsizing and downsizing is changing as young people delay forming families, and as older adults remain healthy and in their homes for longer (Metrolinx, 2016b).

\footnotetext{
${ }^{10}$ The RBC/Pembina Institute survey results are based on an online survey administered by Environics Research Group. The sample group are not home buyers, so the results do not represent the opinions of people actively selecting where to live in the region.
} 
Figure 8. Share of housing types by age group in the GTHA, 2011 (Metrolinx, 2016b).

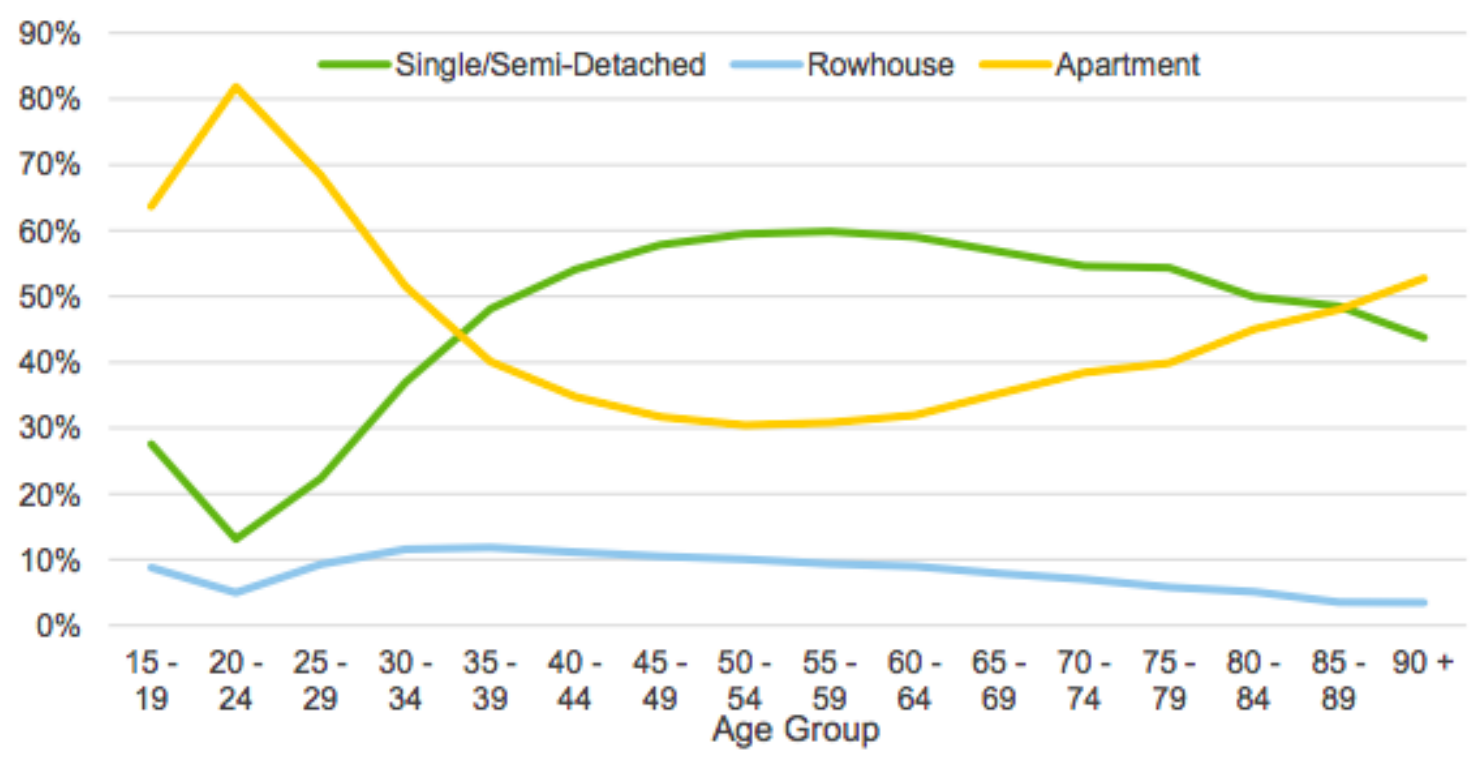

Transit is one of a number of features that makes a community attractive. Other considerations are parks, schools, attractions (like shopping areas) and jobs (Dunphy, et al., 2005). A number of the suburban GO rail stations in the GTHA do not have existing features that attract residents, aside from transit access. For this reason, a comprehensive development plan is desirable to create an environment that can entice buyers.

\subsection{Market Viability}

Historically, the demand for housing in Toronto has been the primary driver for intensification success, as found in a comparison study of Toronto and Sydney (Searle \& Filion, 2011). Toronto, and other urban centres, have been able to achieve high density developments as a result of large population growth and demand for urban living. Suburban markets require a different approach to achieve success. Regardless of government policies, development will only occur if it is financially viable for a private developer, or if there are sufficient incentives that make a development feasible. Transit investment alone will not spur development when the real estate market does not support it (Cervero, et al., 2002). Transit investment causes changes to how growth is distributed, but does not result in new growth (Cervero, et al., 2002). If preferences continue to change, with increased interest in transit access, pricing for TOD will increase and that will make station intensification a more attractive investment opportunity. The following sections discuss barriers to mid-rise residential development, and changes that could be implemented to support intensification. 


\subsubsection{Barriers to Mid-Rise Development.}

Developing around transit stations is risky for developers because suburban households tend to be vehicle oriented and prefer lower density housing forms (Cervero, et al., 2002). Blais (2003) found that smart growth forms, such as mid-rise buildings, were challenging to develop in a suburban context because developers were more interested in developing on greenfield land, and also urban design and density policies were viewed as too demanding. Beaumont (2012) found that the building code, parking requirements, land costs and municipal policies were all barriers to development because they increased the costs for developers in the GTA.

Sotomayor (2013) showed that mixed-use development is only viable in certain areas, like the York Region centre and corridors. Therefore, a blanket policy objective, such as a specified intensification target, may not be achievable in all contexts. The factors that limit demand for smart growth communities and mid-rise forms may change overtime if suburban markets mature and if housing preferences change. This is likely to occur as the price of detached housing rises and congestion continues to worsen, making access to transit a more important consideration. The factors that drive demand for condominiums are: affordability, demographics, transit access, rental market investor interest and quality of life (NBLC, 2016). RER, in addition to ongoing changes in the suburban market (such as demographic change), may result in price increases that compensate for other barriers to development, such as municipal fees and charges.

\subsubsection{Tools to Support Intensification.}

In a suburban context, different tools are needed to encourage development, such as subsidization rather than taxation. This is different than urban areas where extraction from development tends to occur. Many incentives in Ontario have focused on redeveloping brownfield areas, protecting heritage buildings, supporting employment and encouraging affordable housing (Sotomayor, 2013). Intensification is less frequently the focus of financial incentive programs, though there have been some examples like the Ottawa Re-Do-It initiative launched in 1994 (Sotomayor, 2013). The Residential Downtown Intensification (Re-Do-It) initiative waived fees for parkland, development charges, building permit fees and planning application fees (CMHC, n.d). Policy and politics have 
financial impacts. Development charges, density bonuses and other municipal extractions can impact the profitability of a project, and the project approval timeline can be long if there is a lack of political support from residents and/or Council. Beyond financial tools, other strategies that support market viability are expedited approvals, zoning changes and improved government coordination. Table 4 provides a summary of these tools organized by the actor involved. Actions that are in RTP (2018) or the Growth Plan (2017) are noted. 
Table 4. Recommendations for TOD by actor involved

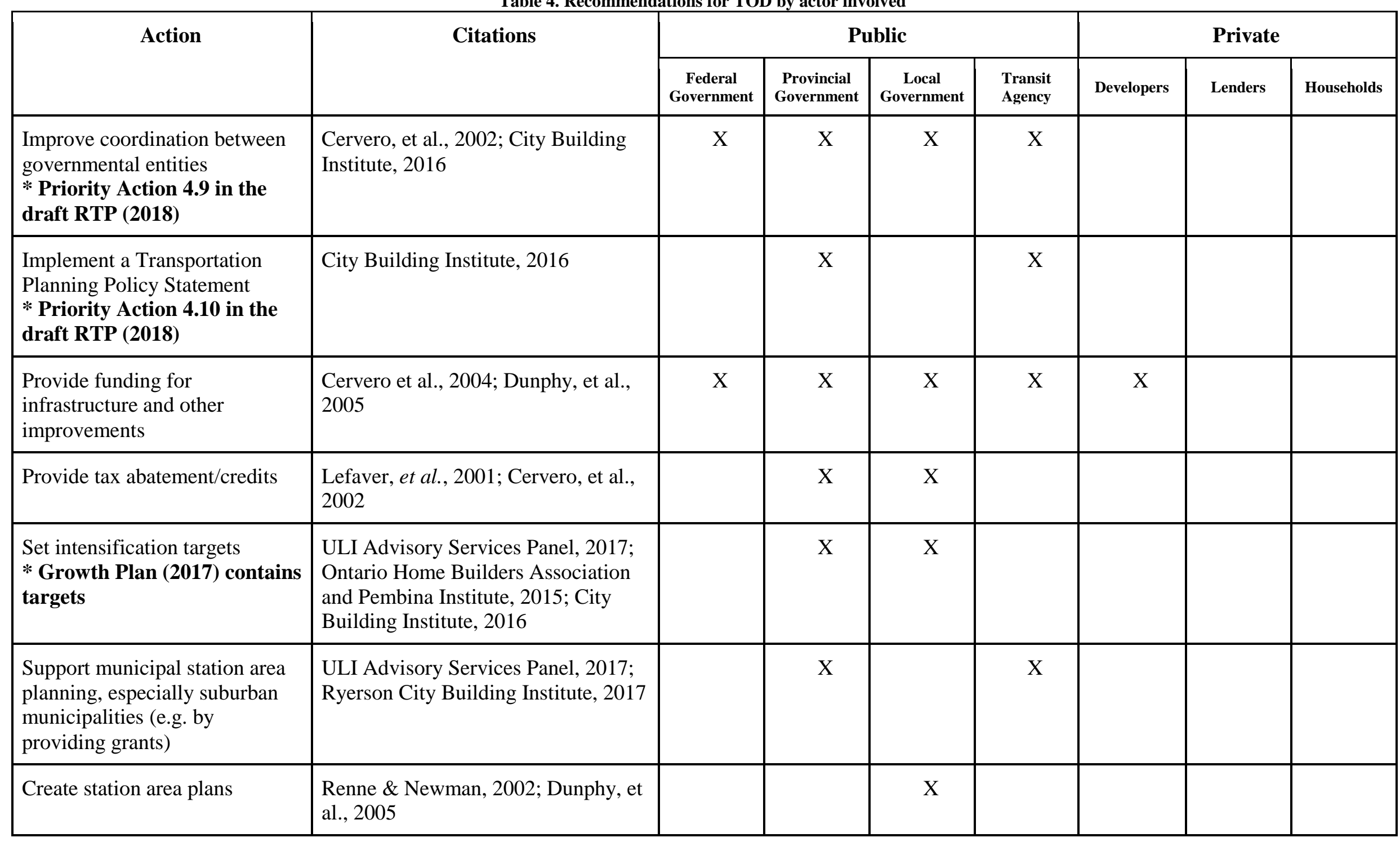




\begin{tabular}{|c|c|c|c|c|c|c|c|c|}
\hline \multirow[t]{2}{*}{ Action } & \multirow[t]{2}{*}{ Citations } & \multicolumn{4}{|c|}{ Public } & \multicolumn{3}{|c|}{ Private } \\
\hline & & $\begin{array}{c}\text { Federal } \\
\text { Government }\end{array}$ & $\begin{array}{c}\text { Provincial } \\
\text { Government }\end{array}$ & $\begin{array}{c}\text { Local } \\
\text { Government }\end{array}$ & $\begin{array}{l}\text { Transit } \\
\text { Agency }\end{array}$ & Developers & Lenders & Households \\
\hline $\begin{array}{l}\text { Require municipal land use plan } \\
\text { prior to making transit } \\
\text { investment and/or prioritize } \\
\text { investment based on } \\
\text { redevelopment feasibility } \\
\text { * Priority Action } 4.2 \text { in the } \\
\text { draft RTP (2018) }\end{array}$ & $\begin{array}{l}\text { Pembina Institute, 2012; City } \\
\text { Building Institute, 2016; Ryerson } \\
\text { City Building Institute, } 2017\end{array}$ & & & $X$ & $X$ & & & \\
\hline $\begin{array}{l}\text { Implement design } \\
\text { standards/guidelines }\end{array}$ & $\begin{array}{l}\text { ULI Advisory Services Panel, 2017; } \\
\text { Porter, 1997; }\end{array}$ & & & $X$ & & & & \\
\hline $\begin{array}{l}\text { Update land use permissions } \\
\text { around stations (e.g. amend the } \\
\text { Zoning by-law and Official } \\
\text { Plan) }\end{array}$ & $\begin{array}{l}\text { Cervero et al., 2004; Dunphy, et al., } \\
\text { 2005; Guthrie \& Fan, 2016; Levine } \\
\text { and Inam, 2004; Cervero et al., 2004; } \\
\text { Hess and Lombardi, 2004; Porter, } \\
\text { 1997; Dunphy, et al., 2005; Niles \& } \\
\text { Nelson, 1999; City Building Institute, } \\
2016\end{array}$ & $\begin{array}{l}\text { *Ministerial } \\
\text { Zoning Order }\end{array}$ & & $X$ & & & & \\
\hline $\begin{array}{l}\text { Reduce parking requirements, } \\
\text { such as by reducing minimum } \\
\text { ratio or removing it all together } \\
\text { * Priority Action } 4.8 \text { in the } \\
\text { draft RTP (2018) }\end{array}$ & $\begin{array}{l}\text { Cervero, 1996; Cervero et al., 2004; } \\
\text { Dunphy, et al., 2005; Pembina } \\
\text { Institute, 2012; Ontario Home } \\
\text { Builders Association and Pembina } \\
\text { Institute, 2015; Cervero, et al., 2002; } \\
\text { City Building Institute, } 2016\end{array}$ & & & $X$ & & & & \\
\hline $\begin{array}{l}\text { Provide greater certainty for } \\
\text { future transit improvements }\end{array}$ & $\begin{array}{l}\text { Guthrie \& Fan, 2016; City Building } \\
\text { Institute, } 2016\end{array}$ & & & & $\mathrm{X}$ & & & \\
\hline $\begin{array}{l}\text { Establish partnerships between } \\
\text { the private and public sectors }\end{array}$ & $\begin{array}{l}\text { Renne \& Newman, 2002; Porter, } \\
\text { 1997; }\end{array}$ & & & $X$ & $\mathrm{X}$ & $X$ & & \\
\hline
\end{tabular}




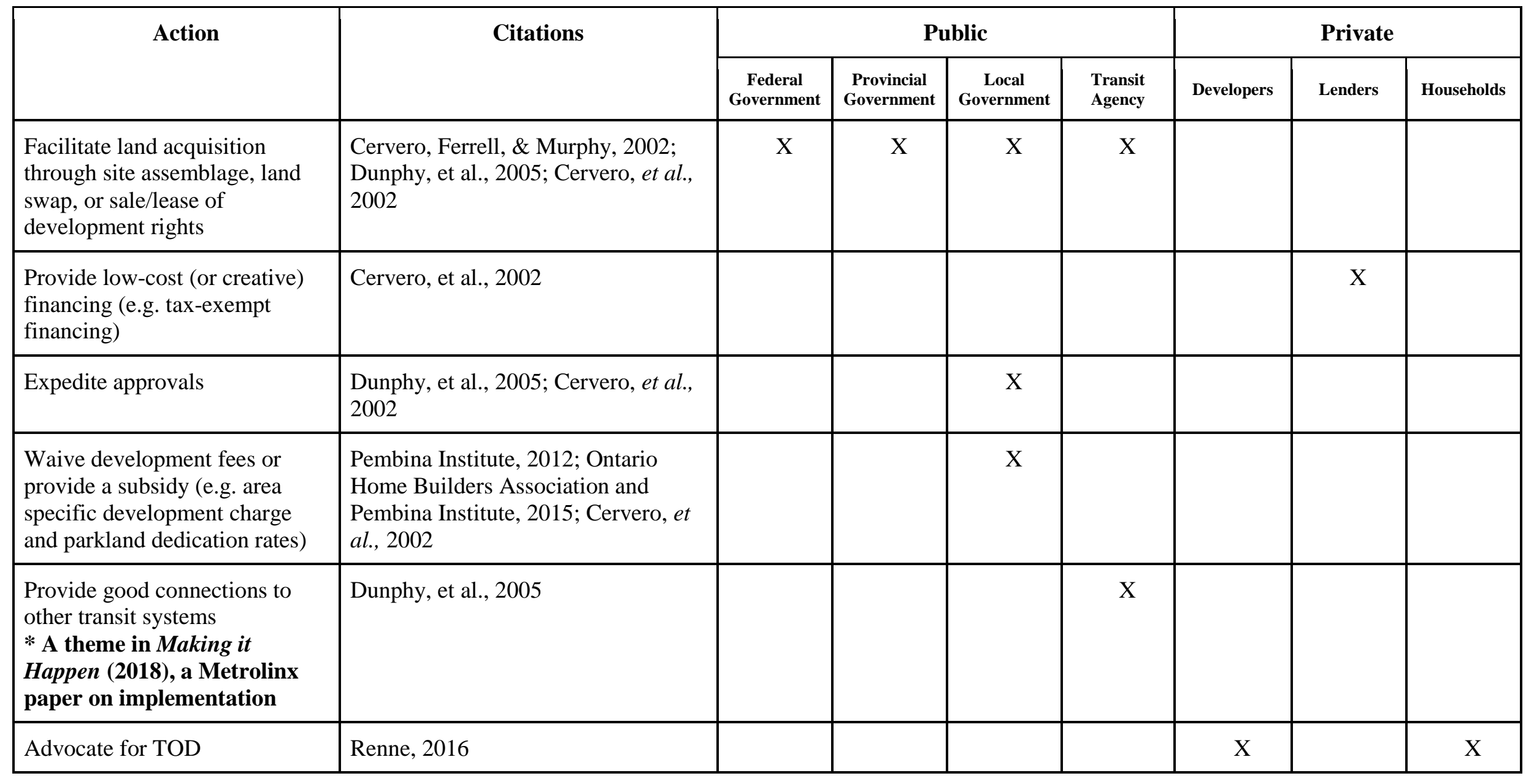




\section{$\underline{4.0}$ Policy Context}

\subsection{Provincial Policy Statement (2014)}

The Provincial Policy Statement (PPS) (2014) is legislated through Section 3 of the Planning Act. The PPS is a land use planning document that addresses topics of climate change, housing, employment, natural resources and natural heritage among others. The PPS encourages TOD. Intensification of existing GO rail stations is viewed as an efficient use of existing infrastructure with the potential to minimize vehicle travel (Ministry of Municipal Affairs and Housing, 2014). Intensification provides an opportunity to increase density and diversity of uses, which are both aims of the PPS. All local and regional planning decisions must conform to the PPS. Section 2.2.4.4 of the Growth Plan (2017) states that an alternative density target for MTSAs may be permitted if intensification cannot be achieved because of provincial policy, like the PPS (Ministry of Municipal Affairs, 2017). An example of an exception could be the presence of agricultural lands or sensitive habitat around a station. Protecting employment lands may also be seen as a reason to approve an alternative target.

\subsection{Growth Plan for the Greater Golden Horseshoe (2017)}

The Growth Plan for the Greater Golden Horseshoe (2017), or "Growth Plan," is a provincial plan that is managed by the Ontario Growth Secretariat, part of the Ontario Ministry of Municipal Affairs and Housing. The plan is legislated through the Places to Grow Act, 2005, S.O. 2005, c. 13. The aim of the plan is to direct where and how growth should occur in the GGH. The plan acts as an urban containment policy that seeks to limit sprawl. The Growth Plan must be consistent with the PPS (2014). The 2006 plan was updated in May 2017. The update included more specific direction for transit station intensification. 
Municipalities are now required to identify the boundaries of MTSAs and set intensification targets, with the Growth Plan (2017) target acting as a minimum. The MTSAs ${ }^{11}$ will be delineated by municipalities. The area will generally refer to an area within a 10-minute walk from a station, or approximately 500 metres. This land area can range depending on the street network. MTSAs are a term used in the Growth Plan (2017). As mentioned, there is an option to request an alternative target (Section 2.2.4.) in the case that intensification is premature or other provincial policy, like the PPS (2014) or Greenbelt Plan (2017), do not support development. The aim of this intensification target is to build complete, mixed-use communities that maximize the number of transit riders. As of May 18, 2017, all planning decisions must conform to the updated Growth Plan (2017). It will take some time before all regional and local municipalities undertake a comprehensive review and update their Official Plans. Conformity is required by 2031.

\subsection{Building Better Communities and Conserving Watersheds Act (2017)}

\section{On December 12, 2017, Bill 139, the Building Better Communities and Conserving Watersheds Act,} received royal assent (Legislative Assembly of Ontario, 2017). There are two amendments in this Bill that will affect development around MTSAs. Amendment 2(15) ${ }^{12}$ allows municipalities to set

\footnotetext{
${ }^{11}$ Major Transit Stations Areas (MTSA) are defined as "the area including and around any existing or planned higher order transit station or stop within a settlement area; or the area including and around a major bus depot in an urban core. Major transit station areas generally are defined as the area within an approximate 500 metre radius of a transit station, representing about a 10-minute walk” (Ministry of Municipal Affairs, 2017, p. 77).

12 The amendment is: (15) The official plan of a single-tier municipality may include policies that identify the area surrounding and including an existing or planned higher order transit station or stop as a protected major transit station area and that delineate the area's boundaries, and if the official plan includes such policies it must also contain policies that,
}

(a) identify the minimum number of residents and jobs, collectively, per hectare that are planned to be accommodated within the area;

(b) identify the authorized uses of land in the major transit station area and of buildings or structures on lands in the area; and

(c) identify the minimum densities that are authorized with respect to buildings and structures on lands in the area. (Legislative Assembly of Ontario, 2017, n.p). 
minimum density targets in MTSAs and amendment 6(36.1.4) ${ }^{13}$ does not allow appeal of maximum densities or maximum and minimum heights around MTSAs (Legislative Assembly of Ontario, 2017). Bill 139 will also make changes to the Ontario Municipal Board (OMB). The OMB will be renamed the Local Planning Appeal Tribunal (LPAT). All LPAT decisions will be required to conform with provincial policies and municipal plans. The implementation of the LPAT will likely result in greater power for municipalities to approve or reject development applications.

\subsection{Regional Transportation Plan (2018)}

The 2041 Regional Transportation Plan (RTP) (2018) is the guiding document for transportation planning and investment in the region and establishes a vision to 2041 for the regional transportation system. Metrolinx is required to develop an RTP under Section 6(1)(a) of the Metrolinx Act (2006) and review the RTP at least every 10 years to ensure it complies with prescribed provincial plans and policies. The RTP's action to “focus development at Mobility Hubs and Major Transit Station Areas along Priority Transit Corridors identified in the Growth Plan" is aligned with the Growth Plan (2017) intensification objectives (Metrolinx, 2018, p. 86). The draft RTP recommends that a Transportation Provincial Policy Statement (TPPS) should be considered to provide greater provincial oversight of transportation planning (priority action 4.1).

${ }^{13}$ The amendment is: Despite subsection (36), there is no appeal in respect of the following:

1. Policies that identify a protected major transit station area in accordance with subsection 16 (15) or (16), including any changes to those policies.

2. Policies described in clauses 16 (15) (a), (b) or (c) or (16) (a) or (b) with respect to a protected major transit station area that is identified in accordance with subsection 16 (15) or (16).

3. Policies in a lower-tier municipality's official plan that are described in subclause 16 (16) (b) (i) or (ii).

4. Policies that identify the maximum densities that are authorized with respect to buildings and structures on lands in a protected major transit station area that is identified in accordance with subsection 16 (15).

5. Policies that identify the maximum densities that are authorized with respect to buildings and structures on lands in a protected major transit station area that is identified in accordance with subsection 16 (16).

6. Policies that identify the minimum or maximum heights that are authorized with respect to buildings and structures on lands in a protected major transit station area that is identified in accordance with subsection 16 (15).

7. Policies that identify the minimum or maximum heights that are authorized with respect to buildings and structures on lands in a protected major transit station area that is identified in accordance with subsection 16 (16) (Legislative Assembly of Ontario, 2017, n.p). 


\subsection{Transit-Supportive Guidelines (2012)}

In 2012, the Ministry of Transportation published guidelines for transit areas. Section 2.6.1 contains direction related to MTSAs. The guidelines state that station planning should be coordinated using land management strategies and area visions. The design of stations should focus on reducing vehicle travel and encouraging active transportation modes. Stations should also be "welcoming, hospitable and vibrant public places that strengthen connections to and between surrounding areas and act as focal points of neighbourhood activity" (Ministry of Transportation, 2012, p. 83).

\subsection{Mobility Hub Guidelines (2011)}

Metrolinx developed Mobility Hub Guidelines (2011) to guide planning around mobility hubs. The mobility hub area is about 800 metres from the station, or a distance that can be comfortably walked. ${ }^{14}$ Like MTSAs, the Mobility Hub Guidelines (2011) encourage intensification. The three stations selected in this report are not mobility hubs, though the guidelines do provide insight for how intensification should occur. Municipalities are not required to conform to the guidelines. Rather, they are a framework to support municipalities to understand good design practices. Not all MTSAs are mobility hubs.

\footnotetext{
14 The definition for mobility hubs are "major transit station areas, as defined in the Growth Plan for the Greater Golden Horseshoe, that are particularly significant given the level of transit service that is planned for them and the development potential around them. They are places of connectivity between regional rapid transit services, and also places where different modes of transportation, from walking to high-speed rail, come together seamlessly. They have, or are planned to have an attractive, intensive concentration of employment, living, shopping and enjoyment around a major transit station. To be identified as a mobility hub, a major transit station area must be located at the interchange of two or more current or planned regional rapid transit lines as identified in the RTP, and be forecasted in the RTP to have 4,500 or more combined boardings in the morning peak period in 2031. In addition, these areas are generally forecasted to achieve or have the potential to achieve a minimum density of approximately 10,000 people and jobs within an 800 metre radius. The primary major transit station area associated with an urban growth centre are also identified as mobility hubs, as are Pearson Airport and Union Station due to their roles as the GTHA's primary international gateways" (Metrolinx, 2011, p. 146).

There are six mobility hub typologies: Central Toronto, Urban Transit Nodes, Emerging Urban Growth Centres, Historic Suburban Town Centres, Suburban Transit Nodes, and Unique Destinations (Metrolinx, 2011).
} 
The Metrolinx Mobility Hub Guidelines (2011) outline a number of guidelines to support growth around mobility hubs, they are:

- 8.1: Develop detailed phasing strategies connected with infrastructure improvements

- 9.1: Encourage development by providing developer incentives such as height and density exchange, flexible zoning and through mechanisms like bonds, debentures, and Tax Increment Financing.

- 9.2: Plan public investment and infrastructure to create and/or enhance development potential

- 9.3: Engage in joint development and other public-private partnership models to capture the land value uplift from transit infrastructure investment

\subsection{Station Area Parking}

Operational policy impacts redevelopment potential. After a system is constructed, operational decisions play a large role in ridership and the success of the investment (Sohoni, et al., 2017). One of the most significant operational decisions Metrolinx makes is parking policy, the primary land use around GO rail stations (Metrolinx, 2016). Increased parking provision has historically resulted in increased ridership (Figure 9) (Metrolinx, 2016). Metrolinx supplies 70,000 parking spaces at rail stations and the number of spaces would need to double by 2031 to keep pace with ridership growth, unless there is a mode shift away from private vehicles (Metrolinx, 2016). In The Next American Metropolis, Calthorpe (1993) states that park-and-ride lots are only suited to stations that have no opportunity for intensification, perhaps the terminus station of a line.

Although parking has traditionally been the focus in attracting ridership to GO rail stations, this is changing. The vision outlined in the Metrolinx Station Access Plan (2016) is to "promote the development of more walkable, higher density communities surrounding GO rail stations, and implement Provincial policy objectives" (p. 2). 
Figure 9. GO rail parking supply and ridership growth (GO Rail Cordon Counts and 2031 GO Rail Ridership

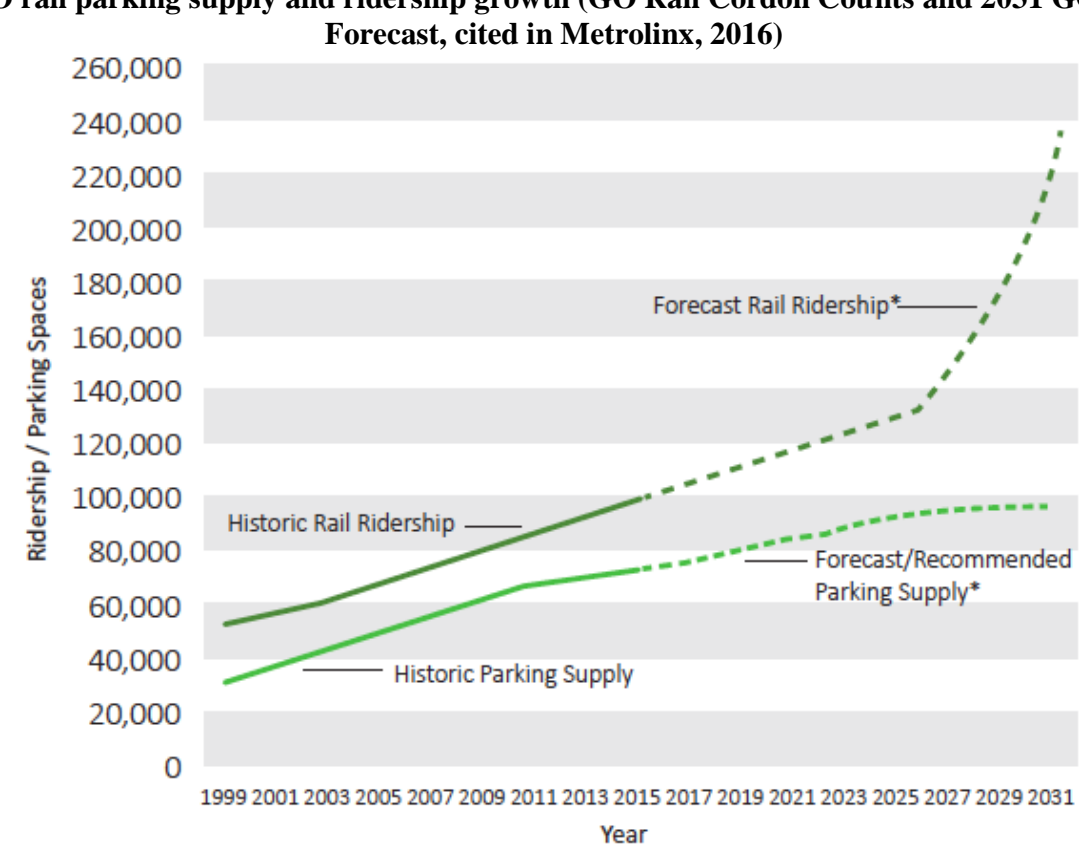

Metrolinx offers free parking at stations. Section 21.1(1)(a) of the Metrolinx Act (2006) allows Metrolinx to charge user fees for parking. The cost of parking is currently recovered through the rail fare (The Regional Municipality of Durham, 2017). The downside of bundling costs is that people who do not use parking spaces subsidize the cost of parking, and people who use parking spaces do not have a cost disincentive to drive.

\subsection{Local Government Policy}

Although many provincial and regional transportation and land use plans are aligned, the application of policy at a local level can be challenging. Municipalities impact the feasibility of development around stations through policy found in Official Plans, Zoning by-laws, parking requirements, and development charges and application fees. Municipalities may adopt intensification policies without an effective implementation plan. Many of the tools outlined in Table 4 address changes municipalities can make to support intensification and TOD. 


\subsection{Station Area Financial Analysis}

The viability of suburban GO rail intensification was explored through a literature review, policy review and residual land value analysis. Three stations in three different municipalities were selected for analysis. All three stations are in employment areas, with nearby residential areas. The general characteristics of the stations areas were that they were:

1. On the Regional Express Rail (RER) network, with 15-minute service;

2. In a built-up area;

3. In a suburban context with low density, vehicle oriented forms;

4. Surrounded by employment lands with nearby residential uses; and

5. In different municipalities.

The three stations selected for analysis were: Appleby (City of Burlington), Ajax (Town of Ajax) and Oshawa (City of Oshawa), shown in Figure 10.

Figure 10. Location of Appleby, Ajax and Oshawa stations

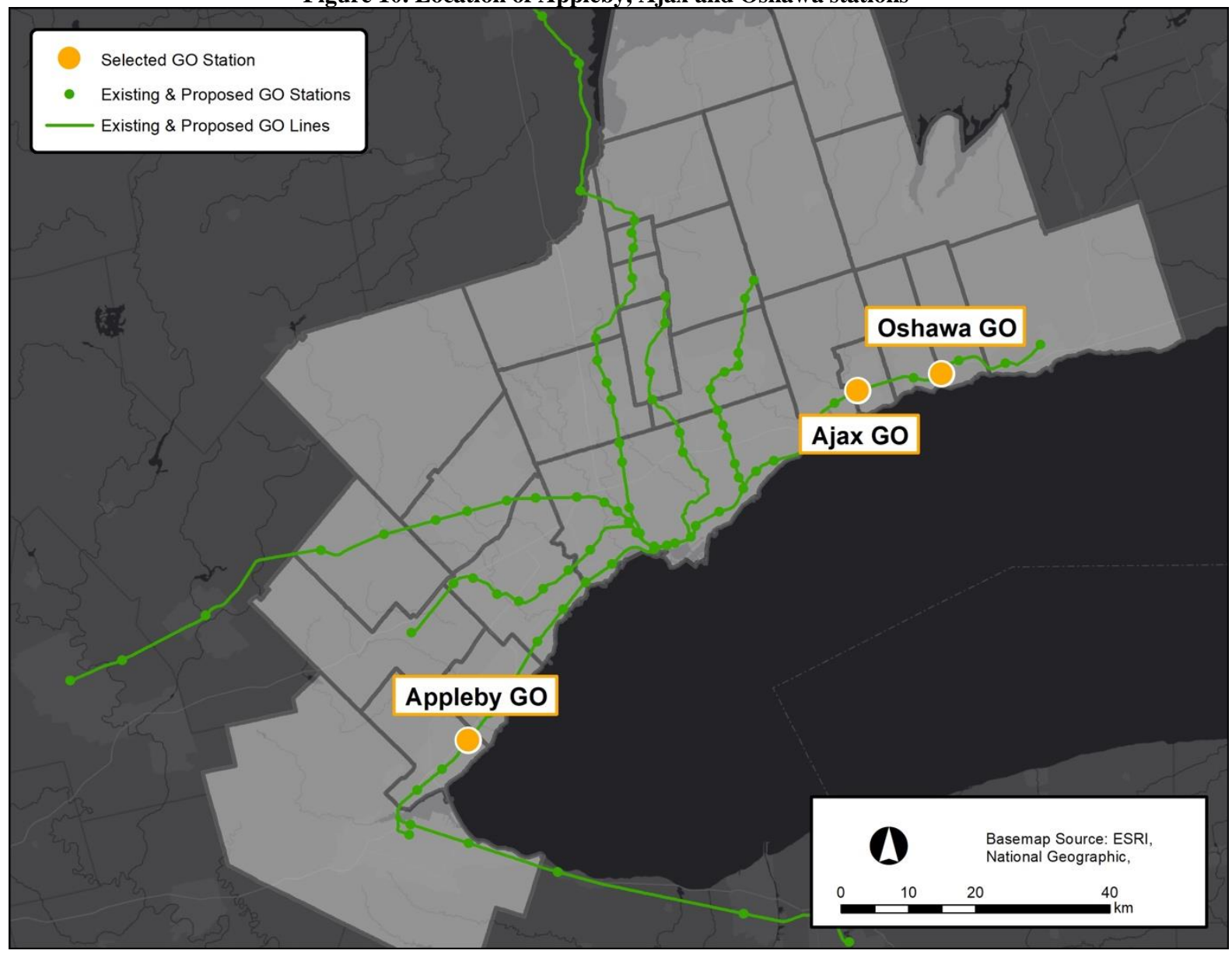

These stations all have a suburban form, often associated with single detached homes, housing ownership, and vehicle use (Moos \& Mendez, 2017). Tables 5 and 6 summarize some key characteristics of the three station areas. The Oshawa station is distinct in that there is housing near 
the station, but not within the immediate station area (about 500 metres). For this reason, data related to housing are not as relevant.

Table 5. Suburban station area characteristics of three stations (NBLC, 2016; Census, 2016)

\begin{tabular}{|l|c|c|c|}
\hline & $\begin{array}{c}\text { Appleby } \\
\text { (Burlington) }\end{array}$ & Ajax (Ajax) & $\begin{array}{c}\text { Oshawa } \\
\text { (Oshawa) }\end{array}$ \\
\hline $\begin{array}{l}\text { Approximate percentage of units that are single } \\
\text { detached homes within 800 metres of station (NBLC, } \\
\text { 2016) }\end{array}$ & $60 \%$ & $75 \%$ & Not available \\
\hline $\begin{array}{l}\text { Percentage of units that are single detached homes in } \\
\text { municipality (Census, 2016) }\end{array}$ & $51 \%$ & $66 \%$ & $56 \%$ \\
\hline Home ownership in municipality (Census, 2016) & $76 \%$ & $86 \%$ & $68 \%$ \\
\hline $\begin{array}{l}\text { Mode choice: } \\
\text { car, truck, van as a driver or as a passenger in } \\
\text { municipality (Census, 2016) }\end{array}$ & $86 \%$ & $79 \%$ & $85 \%$ \\
\hline
\end{tabular}

Table 6. Station area characteristics for Appleby, Ajax and Oshawa related to housing density (NBLC, 2016)

\begin{tabular}{|l|c|c|c|}
\hline & Appleby & Ajax & Oshawa* \\
\hline Household size & 2.5 & 3.2 & \multirow{2}{*}{ Not available } \\
\hline Units per hectare & 12.2 & 9.3 & \\
\hline People per hectare & 30.5 & 29.6 & \\
\hline
\end{tabular}

* Predominantly an employment area

The Development Potential Adjacent to GO Rail Transit Stations (2016) report prepared for

Metrolinx found that there has not been housing construction around the three study stations between

2000 and 2015, shown in Figure 11. The intensification target would be a significant shift in the built form of these three station areas. 
Figure 11. Number of completed units in the GTA within 800 metres of a GO station, 2000-2015 (NBLC, 2016)

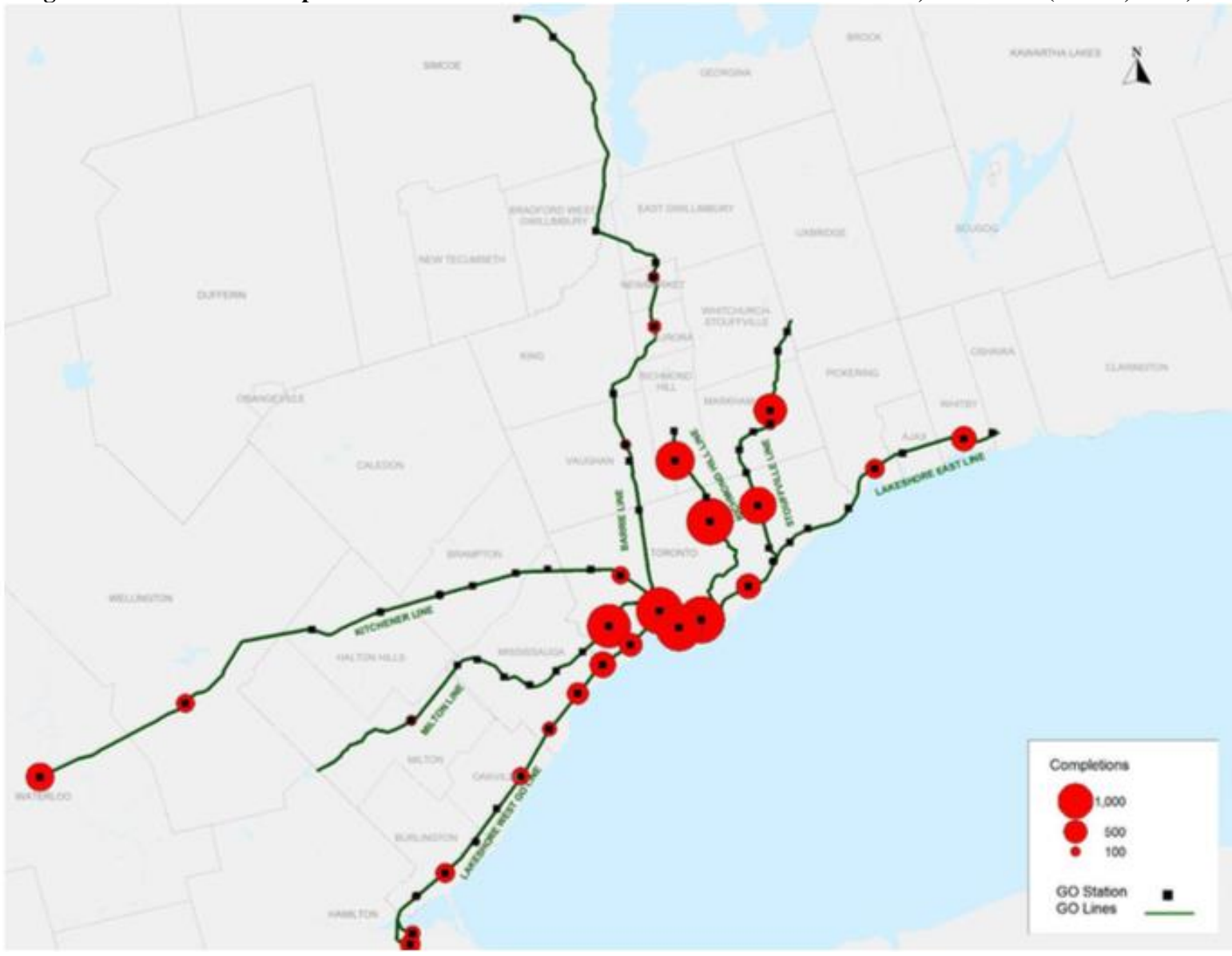

\subsection{Residual Land Value Assumptions}

A residual land value (RLV) analysis was used to determined what land value could be offered to a land owner for the construction of a residential mid-rise building. A low (or negative) land value would indicate that development is not feasible. Conversely, a land value that is comparable to other residential land transactions in the area would likely incent a land owner to sell, and the development would be feasible. The assumptions used for the RLV are summarized in Table 7.

Table 7. RLV inputs for station areas

\begin{tabular}{|c|l|c|}
\hline \multicolumn{1}{|c|}{ Input } & \multicolumn{1}{|c|}{ Notes } & $\begin{array}{c}\text { Varied by Site } \\
\text { (Yes/No) }\end{array}$ \\
\hline Design & $\begin{array}{l}\text { - Height: 8 storeys } \\
\text { - Residential area: 64,000 square feet } \\
\text { - Units: } 70 \\
- \text { Average unit size:775 square feet } \\
-1: 1 \text { resident underground parking, 3:1 visitor surface parking }\end{array}$ & No \\
\hline Hard Costs & $\begin{array}{l}\text { - The Altus Construction Cost Guide (2018) was used to } \\
\text { determine the hard costs. \$215 per square foot was used. }\end{array}$ & No \\
\hline
\end{tabular}




\begin{tabular}{|l|l|c|}
\hline \multicolumn{1}{|c|}{ Input } & \multicolumn{1}{|c|}{ Notes } & $\begin{array}{c}\text { Varied by Site } \\
\text { (Yes/No) }\end{array}$ \\
\hline Soft Costs & $\begin{array}{l}\text { - The based soft costs were assumed to be 25\% of hard costs and } \\
\text { municipal fees and charges. Municipal fees and charges vary by } \\
\text { municipality. }\end{array}$ & Yes \\
\hline Financing & $\begin{array}{l}\text { - Construction loan was assumed to be 75\% of development costs } \\
\text { (hard and soft) over 2 years at a 5.5\% interest rate. Units are } \\
\text { assumed to sell pre-construction and during construction. The } \\
\text { loan would be repaid at the end of the construction period. }\end{array}$ & No \\
\hline Revenue & $\begin{array}{l}\text { - Housing sales are based on the Toronto Real Estate Board } \\
\text { Market Watch report from February 2018 and Real Net (2018), } \\
\text { an Altus service. }\end{array}$ & Yes \\
- Parking spaces were priced at \$15,000 per unit, based on Real \\
Net (2018).
\end{tabular}

The RLVs for each station area had some similar inputs, like hard costs and the building typology, and other inputs varied. Table 7 summarized the key assumptions that varied for each station area.

Table 8. Station area specific inputs

\begin{tabular}{|l|c|c|c|c|}
\hline & Appleby & Ajax & Oshawa & Sources \\
\hline $\begin{array}{l}\text { Pricing (per } \\
\text { square foot) }\end{array}$ & $\$ 600$ & $\$ 575$ & $\$ 525$ & $\begin{array}{c}\text { MLS, Real Net, } \\
\text { TREB }\end{array}$ \\
\hline $\begin{array}{l}\text { Municipal and } \\
\text { regional charges } \\
\text { and fees (\$/unit) }\end{array}$ & $\$ 4,681,795$ & $\$ 1,887,082$ & $\$ 3,672,966$ & $\begin{array}{c}\text { Municipal } \\
\text { website }\end{array}$ \\
\hline
\end{tabular}

\subsection{Appleby Station Analysis}

\subsubsection{Context.}

The City of Burlington is a lower-tier municipality in Halton Region, the upper-tier municipality. It is in the western portion of the GTHA, between the Town of Oakville and the City of Hamilton.

Burlington is a growing community that experienced a 4.3\% increase in population between 2011 and 2016, from 175,779 to 183,314 (Statistics Canada, 2016; Statistics Canada, 2011). In 2016, 2.6\% of the GTHA population lived in Burlington (Statistics Canada, 2016). 


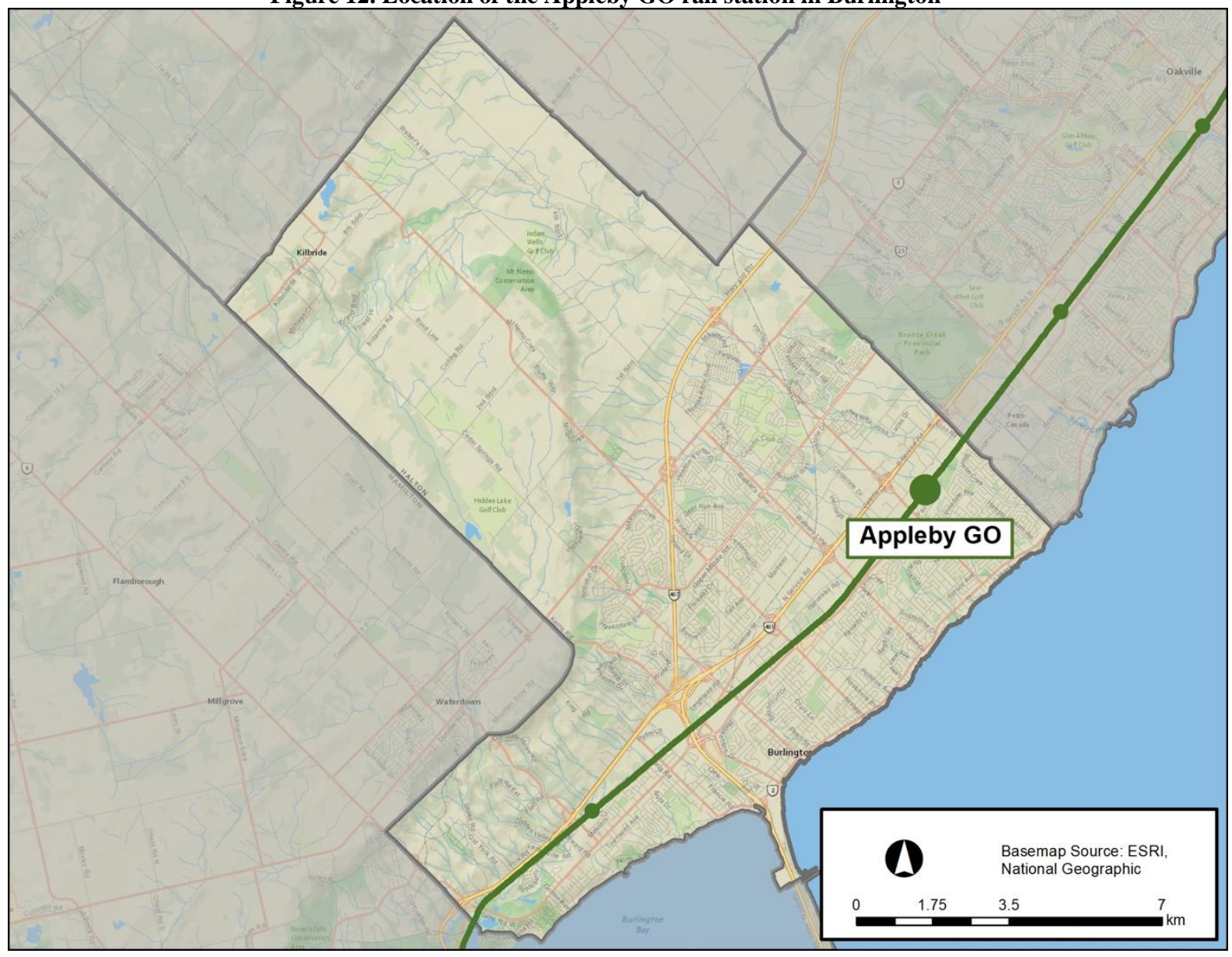

The Growth Plan (2017) anticipates that Region of Halton will grow to 820,000 people and 390,000 jobs by 2031. The city of Burlington is anticipated to grow to 193,000 people and 106,000 jobs (City of Burlington, 2018). This is an increase of 9,686 people from the 2016 population. The 2014 Development Charge Study anticipated that the number of apartment households would grow to 24,619 by mid 2013, an increase of 8,799 from 2011 (Watson \& Associates Economists Lt, 2014).

The Lakeshore West Line provides service to two stations in Burlington, Burlington and Appleby. The Burlington station is near the Downtown Burlington Urban Growth Centre. The Appleby station is in southeast Burlington, just west of Oakville. The station is south of Queen Elizabeth Way (Highway 403).

In 2016, 3,375 people departed from the Appleby station, and 205 traveled to the Appleby station daily (Metrolinx, 2016). This is expected to grow to about 4,001 to 8,000 people departing and 251 to 1,000 people arriving daily in 2031 (Metrolinx, 2016). Most riders (71\%) drive and park at the station (Metrolinx, 2016). This is anticipated to decrease to closer to half of riders by 2031 (46 to 48\%) 
(Metrolinx, 2016). Although a mode shift is anticipated, the overall number of riders is growing so there will be continued demand for parking. There are 2,818 parking spaces and $81-90 \%$ of the spaces tend to be used daily during weekdays (Metrolinx, 2016). A number of changes are proposed to make the station design more accessible. For example, improved paths into the station are proposed to limit pedestrian and vehicle interactions; greater bus frequency seeks to make it easier to link transit trips; and increased cycling infrastructure to make biking more comfortable (Metrolinx, 2016). Metrolinx's GO Rail Station Access Plan (2016) suggested that the south parking lot, which contains about 500 spaces, could be redeveloped in the future. The loss in parking would be compensated using alternative parking strategies, like modular parking and shared parking between multiple uses.

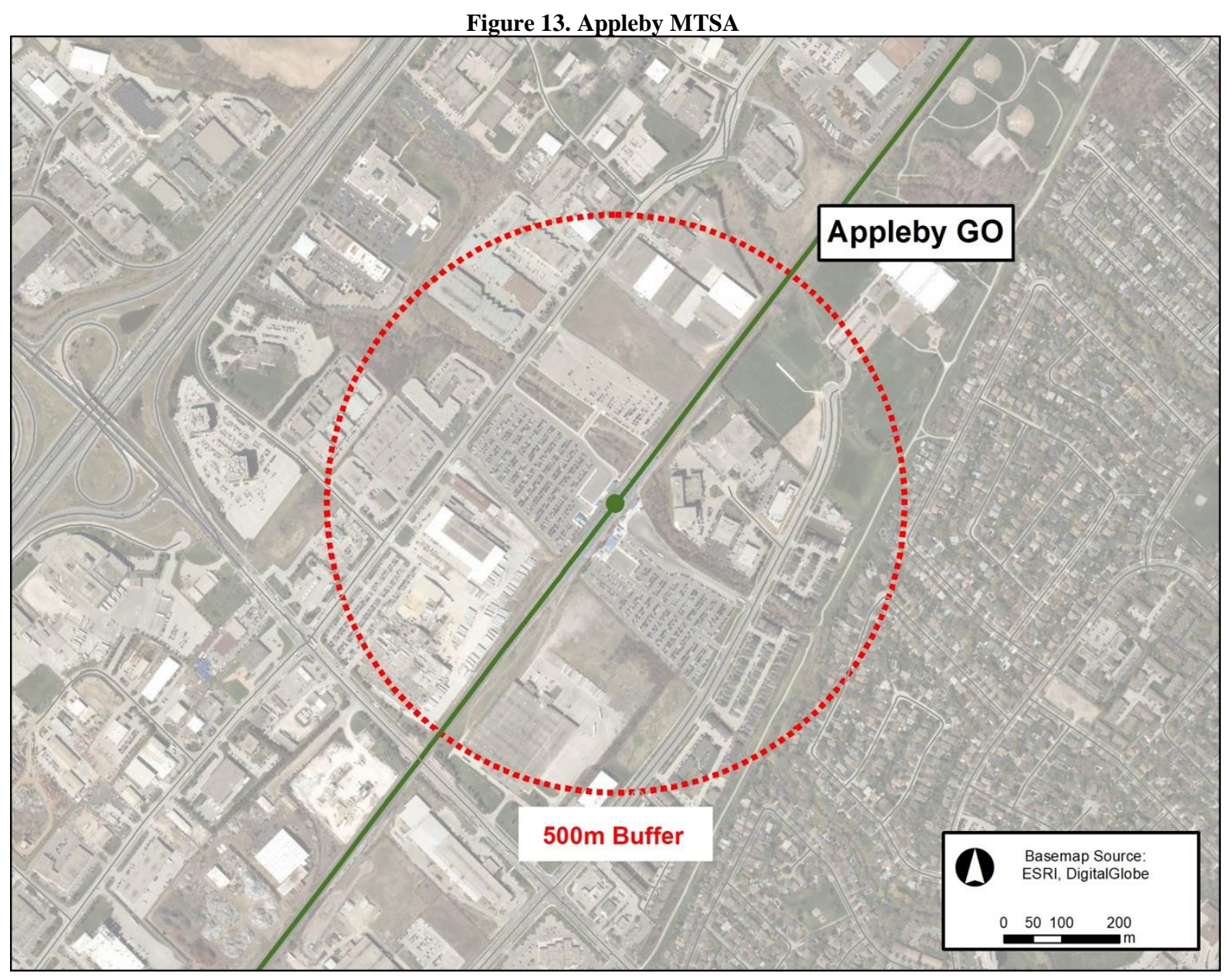

\subsubsection{Local Policy Context.}

The City of Burlington is currently updating the 2008 Official Plan. The updated Official Plan will be a vision for the future of Burlington to 2031. The latest draft Official Plan was released in February 2018. The Official Plan will be presented to Council in April 2018. A focus of the update is to direct 
growth to areas around GO rail stations. For example, an Official Plan (2018) policy (2.3.1.)

regarding mixed use intensification areas is:

i) Mobility hubs consist of areas located within walking distance to major transit station areas, including the Downtown Bus Terminal or GO Rail Stations, which are either currently or planned to be serviced by the frequent transit corridors and GO Transit. The high level of existing or planned transit service within these areas provides an environment within which significant residential and employment growth can be supported. To further support the transit oriented nature of these areas, growth shall occur in the form of compact, mixed-use and pedestrian-friendly areas with residential and employment intensities greater than which exist in the surrounding areas. These are emerging areas in the Urban Structure that represent opportunities to intensify and develop complete communities.

(City of Burlington, 2018, p. 2-11)

The Halton Regional Official Plan (2009) is also being updated. An aim of the update is to "Implement transit supportive land uses/densities along high priority/semi exclusive transit corridors" (Halton Region, 2016).

The Appleby station is in an Urban Area (Schedule A), within the Urban Growth Centre Boundary (Schedule A-1). The station area has three urban structures (Schedule B): Mobility Hubs, Employment Areas, and Mixed Use Nodes and Intensification Corridors. The land uses (Schedule C) are a combination of General Employment and Mixed Use Intensification Areas. The Mixed Use Intensification Areas are Mixed Use Nodes and Intensification Corridors/Urban Corridor. There is a residential Low Density area south of the station and General Employment north of the station. Residential uses are not currently permitted in the Official Plan (2009), though this is changing with new station area planning.

The City of Burlington is undertaking mobility hub planning for Downtown, Aldershot GO, Burlington GO and Appleby GO. A preferred concept for the Appleby GO Station went to Council in December 2017. The next step in the planning process is for the City to develop an area-specific plan and an implementation strategy. Mobility hub planning will introduce new land uses into the station area. The preferred concept is shown in Figure 14. 
Figure 14. Preferred land use concept for the Appleby mobility hub (City of Burlington, 2017)

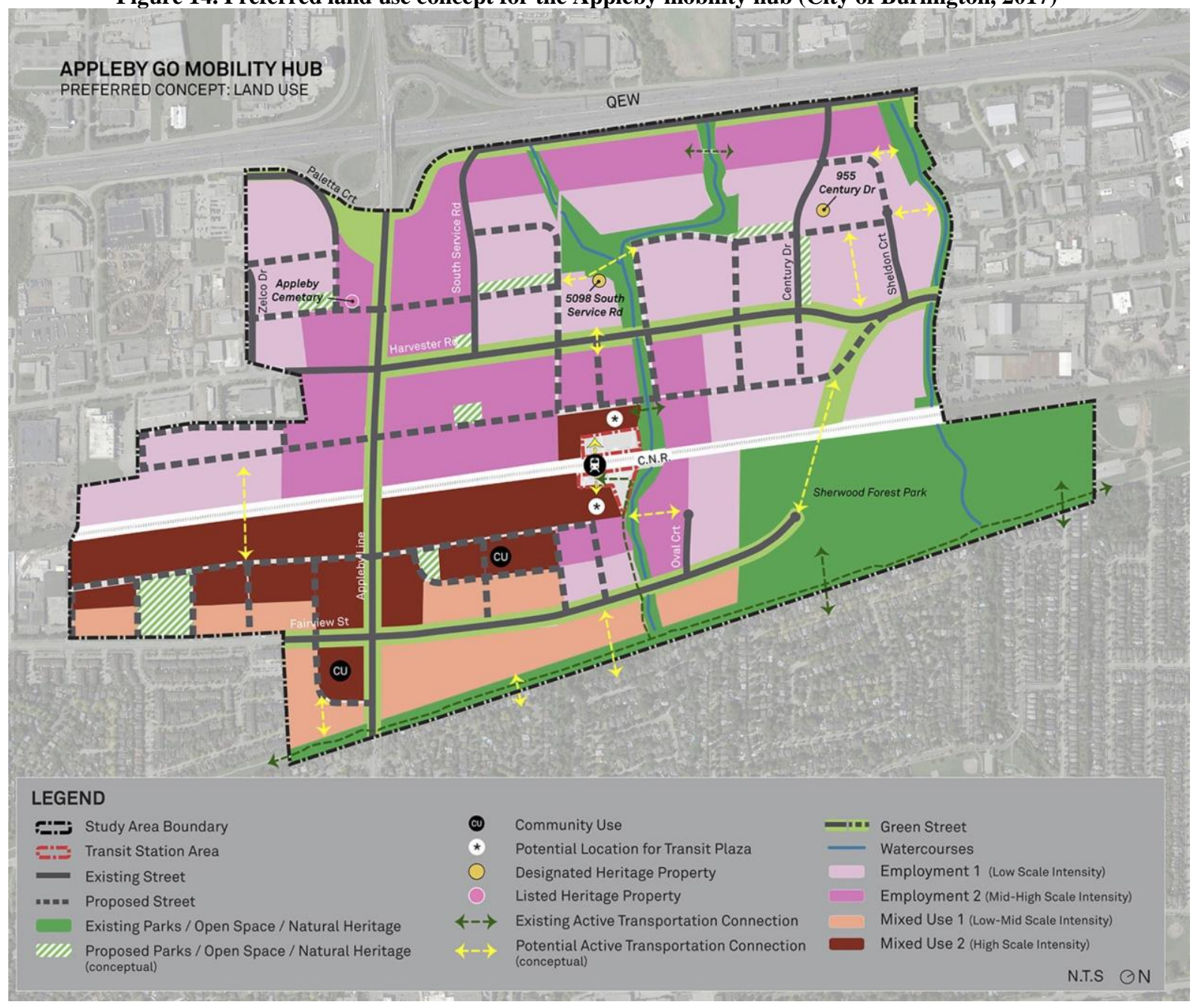




\subsubsection{Intensification Feasibility.}

It is not currently feasible to build a residential mid-rise development near the Appleby station. The RLV analysis returned a negative value. Industrial land near the station is currently selling for $\$ 127$ per square foot, ranging from $\$ 39$ to $\$ 250$ per square foot (Altus, 2018). There are not many examples of residential land sales in the immediate station area. One 2015 sale was reported to be $\$ 42.77$ per square foot (Altus, 2018). In the broader region, residential land is selling for about $\$ 30.41$ per square foot (Altus Group, 2018). Prices are generally higher in the downtown area, ranging from $\$ 49$ to $\$ 72$ per square foot (Altus Group, 2018). The cost for development far exceeds the revenue.

Table 9. Appleby RLV results

\begin{tabular}{|l|c|}
\hline Total Revenue & $\$ 33,482,289$ \\
\hline Total Costs & $\$ 38,902,020$ \\
\hline Profit & $\$ 5,022,343$ \\
\hline Land Value (2018 Value) & $-\$ 9,120,512$ \\
\hline Land Value Per Square Foot (psf) & $-\$ 456$ \\
\hline
\end{tabular}

A 2016 report on development potential around GO rail transit stations found that development potential was moderate around the Appleby station (NBLC, 2016). Transit and the availability of land were strengths, but the planning, site, and market context were only moderate. The planning context for the area is likely to strengthen given the recent station area planning that will likely result in permissions for residential development. Even with planning changes, the market will need to still mature, and incentives are needed to offset the high costs of development.

\subsection{Ajax Station Analysis}

\subsubsection{Context.}

The Town of Ajax is a lower-tier municipality in Durham Region, an upper-tier municipality. It is located between Pickering (to the west and north) and Whitby (to the east). Ajax experienced a 9.2\% increase in population between 2011 and 2016, from 109,600 to 119,677 (Statistics Canada, 2016; Statistics Canada, 2011). In 2016, 1.3\% of the GTHA population lived in Ajax (Statistics Canada, 2016). The Growth Plan (2017) anticipates that the Region of Durham will grow to 970,000 people and 360,000 jobs by 2041. The Region of Durham Official Plan (2017) allocates 137,670 people to Ajax and 49,290 jobs. Growth has been slower than projected. The Official Plan (2017) forecasted that the 2016 population would be 126,325 , about 6,648 more people than there are. 
Figure 14. Location of the Ajax GO rail station in Ajax

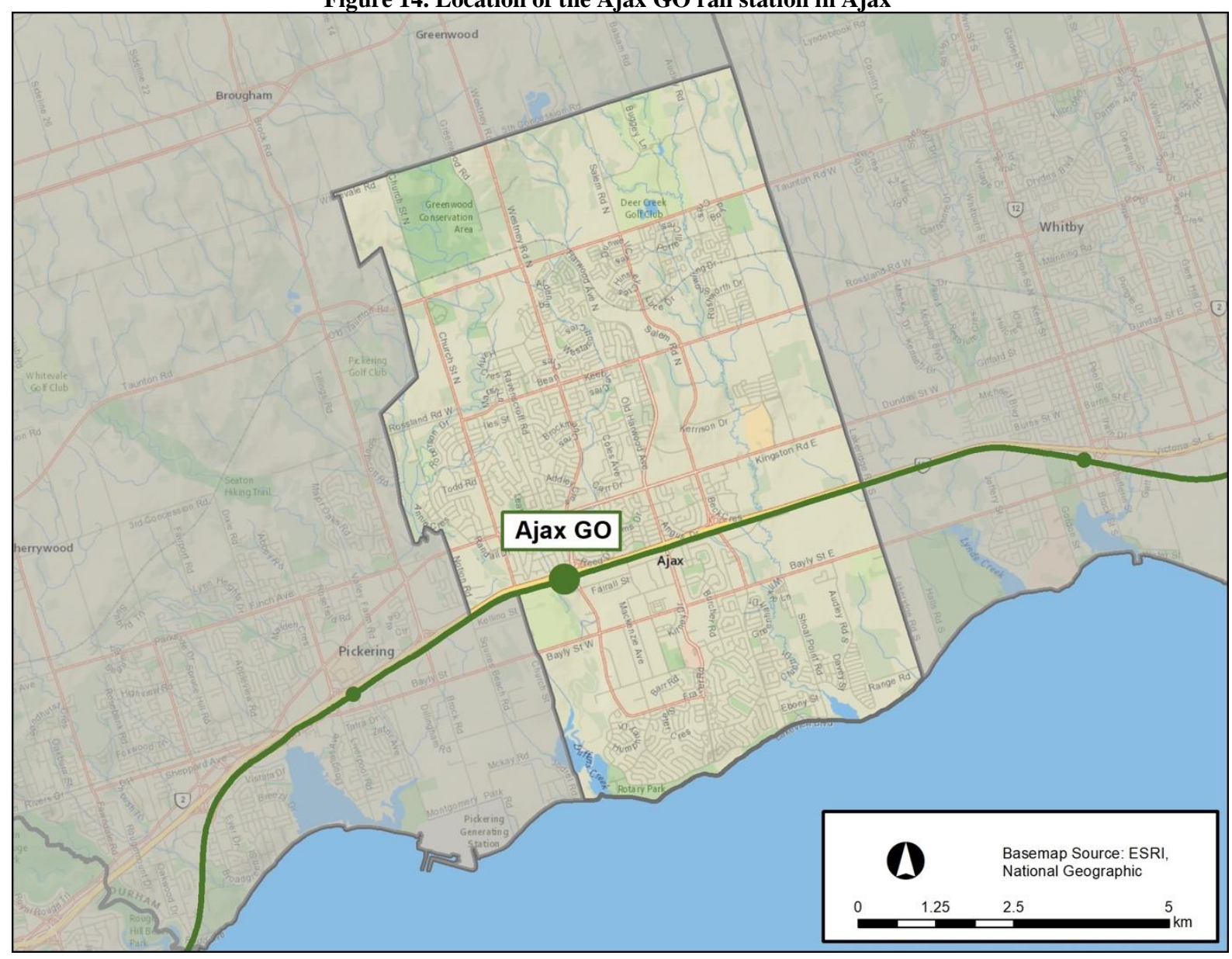

In 2016, 4,525 people departed from Ajax station, and 125 traveled to the Ajax station daily (Metrolinx, 2016). This is expected to grow to about 4,001 to 8,000 people or more departing and between 251 and 1,000 people arriving daily in 2031 (Metrolinx, 2016). Most riders (55\%) drive and park at the station (Metrolinx, 2016). This is anticipated to decrease to 38 to $40 \%$ riders by 2031 (Metrolinx, 2016). There are 2,586 parking spaces and 81 to $90 \%$ of the spaces tend to be used daily. A minimal increase in active transportation is anticipated. The GO Rail Station Access Plan (2016) suggests that the north-east area of the parking lot should be redeveloped to improve walking paths. Employment intensification is also suggested, which might attract more people traveling to the station (Metrolinx, 2016). 


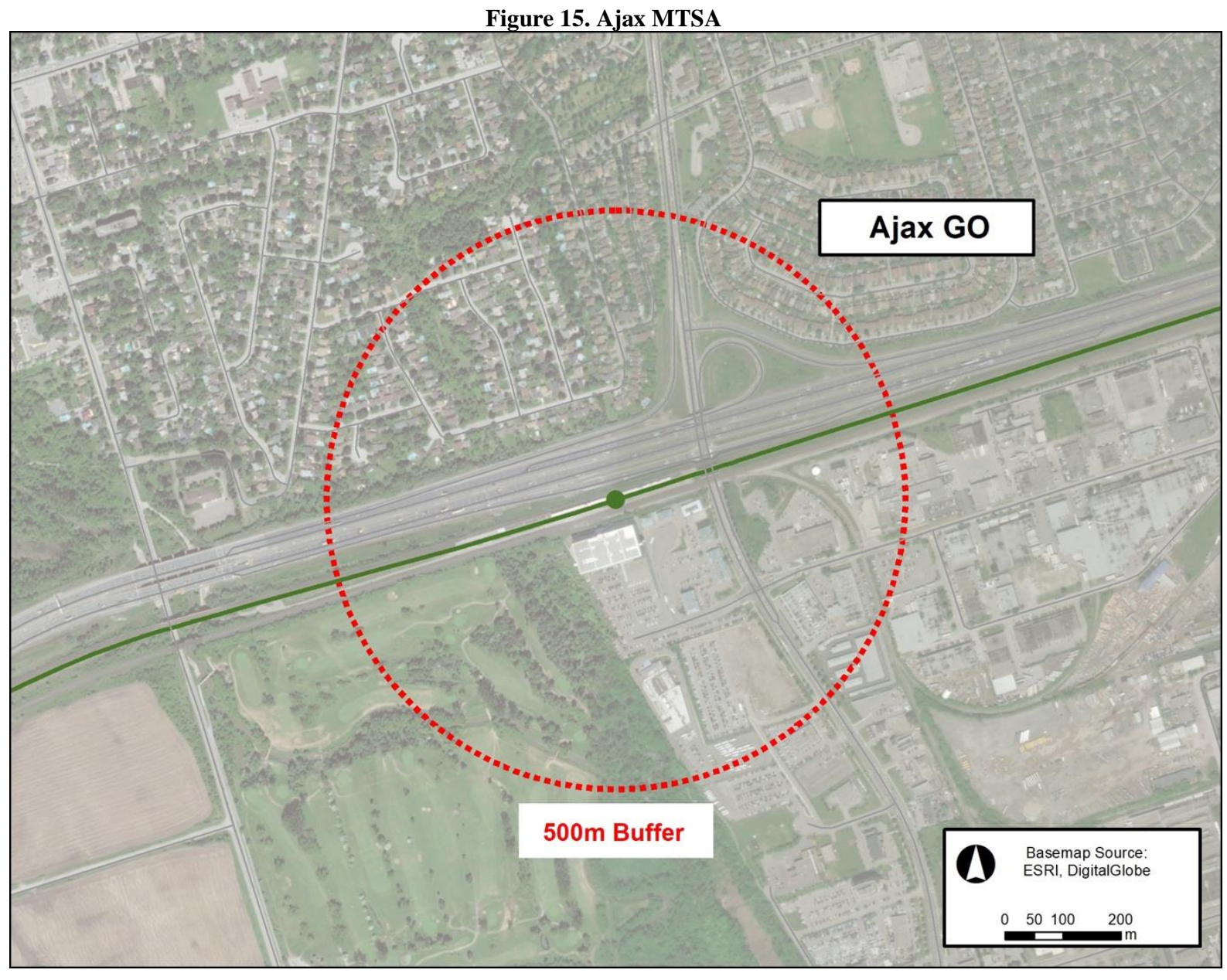

\subsubsection{Local Policy Context.}

The Official Plan (2016) supports intensification around the Ajax GO rail station under policy

\subsubsection{4, GO Transit Station Mixed Use Area:}

The Ajax GO Train Station lands and the area within 500 metres of the GO Station generally on the west side of Westney Road represent an important opportunity to build upon the accessibility and location advantages of the area that will facilitate a high density mixed use area, anchored by employment uses.

The intent is to build on the synergy provided by the GO Train Station and the Durham Region Bus Terminal to create a mixed use centre that includes services for commuters and enables living and working while minimizing car use.

This area is intended to support a high degree of pedestrian amenity with strong connections to transit facilities reducing walking distance to transit. Pedestrian and cycling facilities to support non-auto modes of transit are encouraged as part of any redevelopment within this

Area.

An important feature of this area is the opportunity presented for office or livework employment as well as residential uses situated next to established high order transit facilities.

(p. 77) 
The GO station is in the Built Boundary (Schedule A-2) and in the GO Transit Station Mixed Use Area, which is considered a type of employment land under the land use plan (Schedule A-1). West of the station is a golf course that is designated Environmental Protection, and part of the greenlands system. Directly north of the station is Highway 401. North of the station and highway 401 is a Low Density Residential area. East and south of the station are employment lands, including General Employment and Prestige Employment ${ }^{15}$. There are some non-vehicle transportation options in the area. Westney Road is a Rapid Transit Route (Schedule C-2), and bike lanes are proposed in the area around the station (Schedule C-3) (Town of Ajax, 2016). A 2010 study suggested that the GO Transit Station Mixed Use Area should accommodate 350 units and 650 people. The intensification vision suggests a "high density mixed use node, anchored by employment uses" (GHK International, du Toit Allsopp Hillier, and AECOM, 2010, p. 39).

\subsubsection{Intensification Feasibility.}

It is not currently viable to develop around the Ajax GO rail station. Industrial land near the station is currently selling for $\$ 146$ per square foot (Altus, 2018). Residential land sales appear to be slightly lower, ranging from $\$ 40$ to $\$ 73$ per square foot (Altus, 2018). The RLV analysis found that the value of the land is negative; the cost of development is greater than the revenue generated from construction.

Table 10. Ajax RLV results

\begin{tabular}{|l|c|}
\hline Total Revenue & $\$ 32,122,291$ \\
\hline Total Costs & $\$ 36,292,313$ \\
\hline Profit & $\$ 4,818,344$ \\
\hline Land Value (Present Value) & $-\$ 7,850,787$ \\
\hline Land Value PSF & $-\$ 393$ \\
\hline
\end{tabular}

A 2016 report on development potential around GO rail transit stations found that development potential was moderate (NBLC, 2016). Transit was viewed as a strength, mostly because this station

\footnotetext{
${ }^{15}$ Prestige employment refers to lands with good access to primary roads (such as Highway 401). Development in these areas is expected to be high quality given the visibility of the location (Town of Ajax, 2016).
} 
is part of the RER network. The planning context was a moderate influence, as was the land availability. The site and market context were weak.

\subsection{Oshawa Station Analysis}

\subsubsection{Context.}

Oshawa is a lower-tier municipality in the Durham Region. It is in the eastern portion of the GTHA, between Whitby and Clarington. Oshawa is a growing community that experienced a $6.6 \%$ increase in population between 2011 and 2016, from 149,607 to 159,458 (Statistics Canada, 2016; Statistics Canada, 2011). In 2016, 1.7\% of the GTHA population lived in Oshawa (Statistics Canada, 2016). The Growth Plan (2017) anticipates that the Region of Durham will grow to 970,000 people and 360,000 jobs by 2041. The Region of Durham Official Plan (2017) allocates 197,000 people to Oshawa and 90,790 jobs. Growth has been slower than projected. The Official Plan (2017) forecasted that the 2016 population would be 165,390 , about 5,932 more people than there are. 


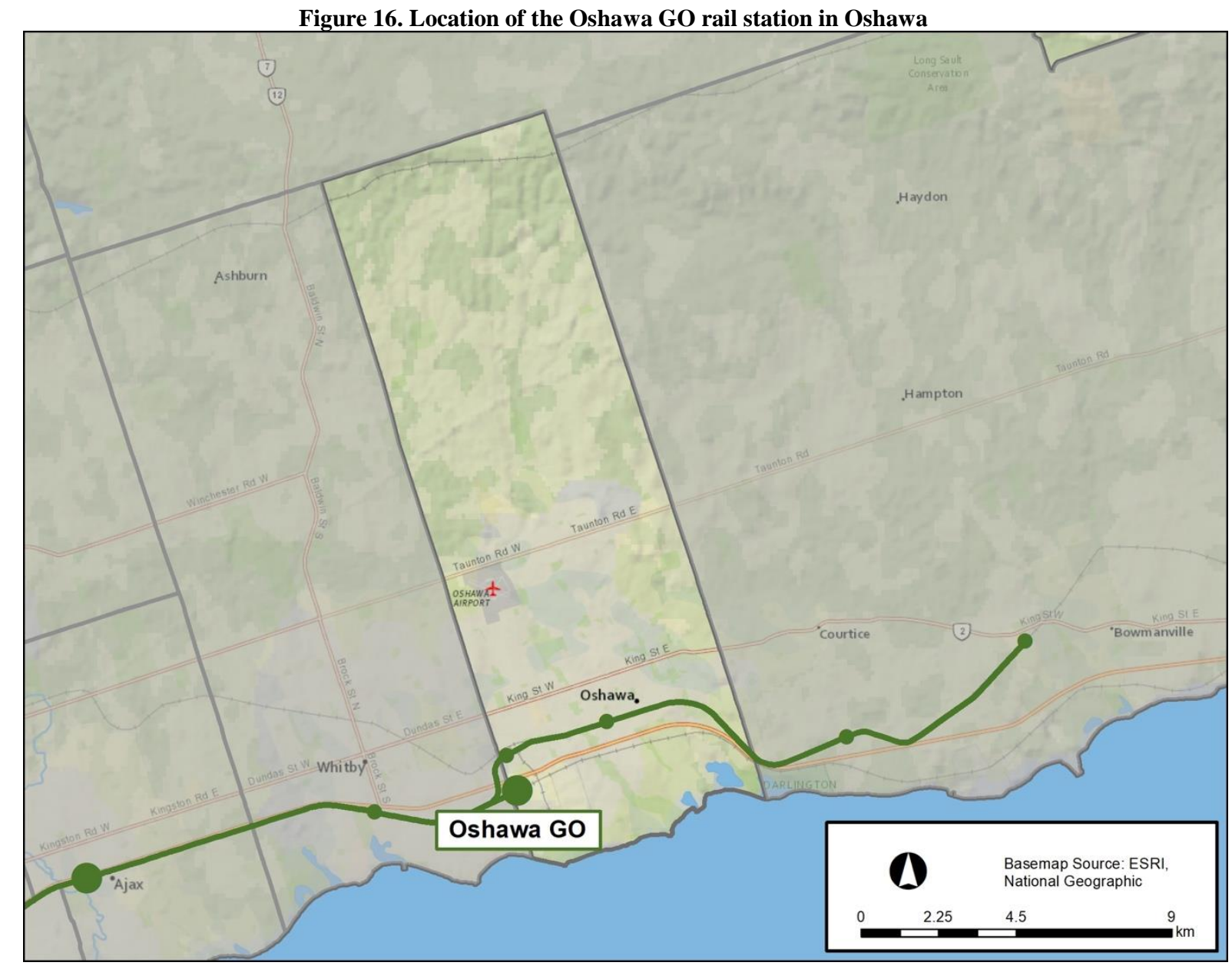

There is one existing GO rail station in Oshawa, and two proposed. The Bowmansville extension is expected to begin construction in 2019 and be completed in 2024 (The Oshawa Express, 2018, March 1; Metrolinx, 2015). The two new stations will be located at Thornton Road and Ritson Road. The existing Oshawa station was recently rebuilt to combine the GO rail station with the VIA Rail station (Ministry of Transportation, 2017). The new station opened in 2018. The Oshawa station is just east of the Whitby municipal boundary.

In 2016, 1,650 people departed from the Oshawa station, and 200 traveled to the Oshawa station daily (Metrolinx, 2016). This is expected to grow to 2,001 to 4,000 people or more departing and 256 to 1,000 people arriving daily in 2031 (Metrolinx, 2016). Most riders (65\%) drive and park at the station (Metrolinx, 2016). This may slightly decrease to 60 to 62\% riders by 2031 (Metrolinx, 2016). There are 2,399 parking spaces and 90 to $100 \%$ of the spaces tend to be used daily. Several changes are proposed to make the station design more accessible to non-vehicle modes. However, vehicle travel is predicted to continue to be the primary mode of transportation. Proposed improvements 
include a better pedestrian connection to Thornton Road and increased bus frequencies. No cycling improvements are currently proposed (Metrolinx, 2016). Metrolinx's GO Rail Station Access Plan (2016) suggests expanding the existing parking east of the station by 400 spaces to encourage more ridership.

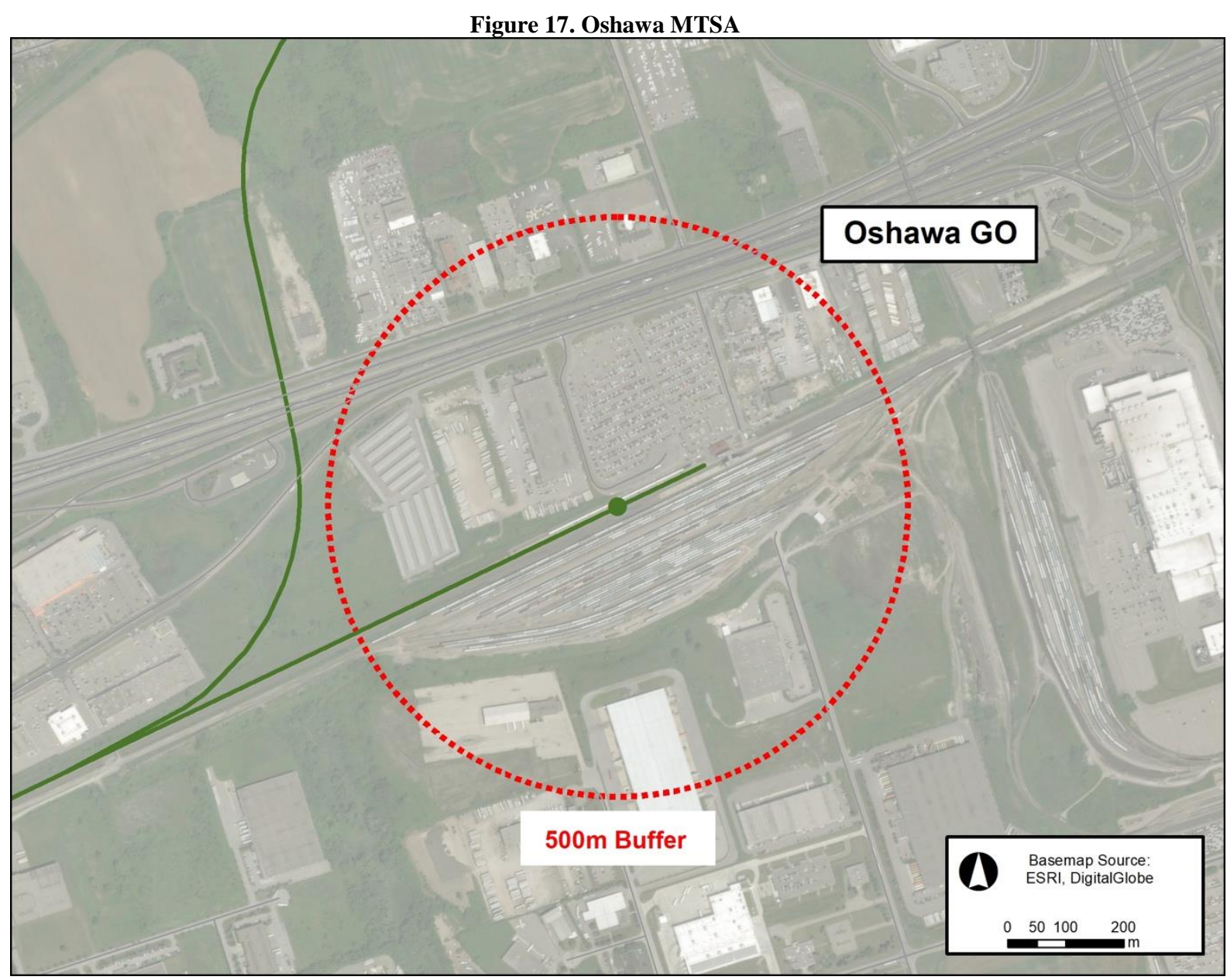

\subsubsection{Local Policy Context.}

The City of Oshawa Official Plan was approved in 1987 and has gone through many updates, the most recent being in December 2017 (City of Oshawa, 2017). The Official Plan (2017) supports intensification around transportation hubs and commuter stations (policy 2.1.7).

2.1.7.1 It is the intent of this Plan to ensure that lands surrounding existing and planned Commuter Stations are used for development that complements and optimizes the support of transit services. In accordance with Policy 3.3.3 of this Plan, an area of influence surrounds Commuter Stations, within which development shall: 
(a) Consist of a mix of land uses at higher densities, in a compact, intensive urban form, to facilitate the provision and use of transit, where the existing or planned Commuter Station is served by heavy rail; or

(b) Over the long term, consist of a mix of land uses at higher densities, in a compact, intensive urban form, to facilitate the provision and use of transit, where the planned Commuter Station is not served by heavy rail.

(City of Oshawa, 2016, p. 2.21)

The station is in an Industrial area (Schedule A). It is in the Renaissance Community Improvement Area, Sub-Area 'B' (Schedule C-1). This area has been identified as having pressure for higher density development, which is a concern given a lack of road infrastructure and a variety of land use conflicts (policy 4.3). There is a small area of land west of the station that is part of the Natural Heritage System (Schedule D-1) and Riparian Corridor (Schedule F1-A) (City of Oshawa, 2016).

\subsubsection{Intensification Feasibility.}

The RLV analysis showed that mid-rise residential development is not viable. The land value is negative, as shown in Table 11. Industrial land near the station is currently selling for $\$ 90$ per square feet (Altus, 2018). Residential land has sold for less than industrial land in the area (Altus, 2018). The market would need to mature and/or costs must decrease significantly to make development viable.

Table 11. Oshawa RLV results

\begin{tabular}{|l|c|}
\hline Total Revenue & $\$ 29,402,293$ \\
\hline Total Costs & $\$ 37,893,191$ \\
\hline Profit & $\$ 4,410,344$ \\
\hline Land Value (Present Value) & $-\$ 11,268,444$ \\
\hline Land Value PSF & $-\$ 563$ \\
\hline
\end{tabular}

A 2016 report on development potential around GO rail transit stations found that development potential was low (NBLC, 2016). A driving factor is that the land around the station is designated for employment uses. Land availability is good, but the planning context is poor. The site and market context were also determined to be poor. Transit is a strength for this station because it is part of the RER network. 


\section{Discussion}

The Appleby, Ajax and Oshawa GO rail station areas are tangible examples of areas that are expected to intensify under the Growth Plan (2017). These stations areas are impacted by local and regional forces. At a local level, the market conditions and support (or lack thereof) from Council impact the feasibility of development. At a broader level, Provincial and regional planning drives local government policies that support intensification.

These stations present an important opportunity for intensification in the region. Growth Plan (2017) policies that restrict greenfield development and protect natural and agricultural areas support the movement towards locating the majority of growth in built up areas. Demographic changes, like an aging population and increased preference for livable communities, means that TOD is a location choice that will likely increase in popularity. Lastly, worsening vehicle congestion and housing affordability mean that housing near transit is becoming increasingly desirable. Although there is indication that suburban markets are maturing, planning changes are needed to support this suburban intensification.

\subsection{Considerations for Local Governments}

Some municipalities have initiated station area planning. Burlington has developed station area plans, and they are developing a public engagement program about intensification (City of Burlington, n.d.). When planning, municipalities should consider adopting plans that have some level of flexibility. In Planning the New Suburbia: Flexibility by Design, Friedman (2002) states that the evolution of suburbs should balance change with maintaining the character of the community. A technique for facilitating change is flexibility in land use controls. Zoning in suburban areas can often be very rigid with little opportunity for a mix of uses and different housing forms.

Existing and emerging policies impact station area planning that present tradeoffs for municipalities to consider. As mentioned in the literature review, developing a mixed-use area often contradicts with aims to protect employment areas. Another emerging policy is inclusionary housing. In December 2017, the Province of Ontario proposed an inclusionary housing regulation that would require that 10 percent of units in transit station areas are affordable. Consultation on this regulation is currently 
underway. According to the proposed regulation, affordable housing provision would be provided in combination with financial incentives from the municipality, such as relaxation in zoning or fee waiver (Environmental Registry, 2017). This policy aligns with the Growth Plan (2017) policy 2.2.4.9.a) that states that development around MTSAs should include, where appropriate, affordable housing.

\subsection{Considerations for Metrolinx}

Metrolinx, the operator of GO rail stations, is governed by the Metrolinx Act (2006). Section 5(1)(i) of the Act states that an objective of Metrolinx is to ensure that transportation policies conform with the Growth Plan. The Act empowers Metrolinx to act on regional transit system matters; however, the Act does not give Metrolinx land development powers. Section 16(2)(a) allows land acquisition and sale for transportation infrastructure projects specifically, and Section 29(1)(c) reinforces this by stating that assets cannot be sold unless it is for a purpose aligned with the organization's objectives. Metrolinx does not currently have the authority to sell or lease land to another organization for residential or employment land development.

In addition to critique concerning the policy structure supporting transportation planning, there is also critique of Metrolinx's governance structure. Organizations like the Toronto Region Board of Trade and individuals like David Quarmby, from Transport for London (TfL), have stated that there should be an organization that directly coordinates transportation across the region (Toronto Region Board of Trade, 2017; Neptis, 2014). For example, TfL provides strategic planning for all transit, and local operators are the service operators (Neptis, 2014). This idea is not universally popular, especially since different municipalities have different transit preferences (Burda, 2017 December 4). Linked to challenges in governance, is also a limitation in the revenue tools that Metrolinx has access to (Slack \& Spicer, 2014).

\subsection{Considerations for the Province}

The RTP (2018) recommends that the province develop a Transportation Planning Policy Statement (TPPS), as does the Live Where You Go (2012) report. The Minister, under Section 31.1(1) of the Metrolinx Act (2006), can issue policy statements, like a Provincial Policy Statement (2014), for 
transportation. A TPPS would require broader municipal compliance with transportation policy. Metrolinx cannot currently enforce compliance with the RTP, but rather seeks to implement the RTP through municipal partnerships and funding allocation. Implementation of the Mobility Hub Guidelines (2011) and the Growth Plan (2017) intensification targets would be aided by alignment of municipal Official Plans, Transportation Master Plans and Secondary Plans. Additionally, the Metrolinx Act (2006) could be amended to allow Metrolinx to redevelop lands around stations. This could be done through an amendment to the Metrolinx Act (2006) or through Section 42(1)(g), which grants power to the Minister to make or change regulation.

\subsection{Recommendations}

The key recommendations to support intensification are:

That the Province (and Minister of Transportation):

1. Amend the Metrolinx Act (2006) to grant Metrolinx power to participate in land development around stations.

2. Create a Transportation Provincial Policy Statement.

That Metrolinx:

3. Align station planning (new stations and improved service) with land-use planning that supports the Growth Plan (2017) intensification target.

4. Implement user fees for parking to encourage alternative transportation modes and carpooling.

That municipalities:

5. Rezone lands around GO rail station areas to allow for higher intensity residential and employment development.

6. Expedite the development approval process.

7. Reduce development charges and parkland dedication fees near stations for areas where the market does not support higher density forms.

8. Reduce parking requirements.

The above recommendations are the minimum tools that should be implemented to support intensification. Other tools, such as those listed in Section 4, should be considered based on areaspecific characteristics.

\subsection{Limitations and Next Steps}

The residual land value analyses were for a single hypothetical building, rather than a comprehensive MTSA design. A more comprehensive analysis of the station area redevelopment could explore the viability of redeveloping an entire station area. Additionally, there are several site- 
specific considerations that impact the viability of development that were not included in the development costs. For example, significant contamination can add large remediation costs. This would likely be a large concern given that stations are located in industrial areas. 


\subsection{Conclusion}

Understanding the local impact of provincial policy is important. The report from the Advisory Panel for the Coordinated Review (2015) found that about 80 percent of the GTHA's GO rail stations only have a third of the density required by the new Growth Plan (2017) (Advisory Panel, 2015). The intensification target cannot be achieved by only building ground-related housing forms, which are the forms that are currently demanded in suburban markets (Ministry of Municipal Affairs and Housing, 2015). Different strategies will be needed in the suburban market to achieve provincial intensification goals. There is extensive research on TOD in North America and many Torontospecific studies on intensification that provide examples of tools to support intensification.

Implementation of these tools is what is needed now. A mix of tools, rather than one alone, are needed to support intensification. Additionally, a different mixture of tools will likely be for different stations. Suburban transit oriented development is an opportunity for the Greater Toronto and Hamilton Area to grow responsibly and by building walkable communities with a diversity of housing options near transit. 


\section{Appendix 1: Residual Land Value Analysis Results}

Table 12. Residual land value analysis for a theoretical eight story condominium building in Appleby, Ajax and Oshawa

\begin{tabular}{|lccc|}
\hline & Appleby & Ajax & Oshawa \\
\hline Development Assumptions & & & \\
\hline Total Number of Units & 70 & 70 & 70 \\
Average net Unit Size & 775 & 775 & 775 \\
Net to Gross & $15 \%$ & $15 \%$ & $15 \%$ \\
Total GFA & 64,000 & 64,000 & 64,000 \\
Parking Ratio & $1: 1$ & $1: 1$ & $1: 1$ \\
Total Parking & 70 & 70 & 70 \\
Total Parking Sold & $80 \%$ & $80 \%$ & $80 \%$ \\
& 56 & 56 & 56 \\
Average Gross Parking Space & 400 & 400 & 400 \\
Altus Cost Guide Construction Costs PSF & $\$ 215$ & $\$ 215$ & $\$ 215$ \\
Revenue & & & \\
PSF & $\$ 600$ & $\$ 575$ & $\$ 525$ \\
Average Unit Price & $\$ 465,000$ & $\$ 445,625$ & $\$ 406,875$ \\
Parking Sale Price & $\$ 15,000$ & $\$ 15,000$ & $\$ 15,000$ \\
Total Revenue & $\$ 33,482,289$ & $\$ 32,122,291$ & $\$ 29,402,293$ \\
\hline
\end{tabular}

\begin{tabular}{|lccc|}
\hline Costs & & & \\
\hline Hard Costs & $\$ 13,843,986$ & $\$ 13,843,986$ & $\$ 13,843,986$ \\
Soft Cost & $\$ 8,133,292$ & $\$ 5,523,584$ & $\$ 7,124,463$ \\
Financing & $\$ 16,924,742$ & $\$ 16,924,742$ & $\$ 16,924,742$ \\
Total Costs & $\$ 38,902,020$ & $\$ 36,292,313$ & $\$ 37,893,191$ \\
Total Cost per Unit & $\$ 554,211$ & $\$ 517,033$ & $\$ 539,839$ \\
\hline
\end{tabular}

\begin{tabular}{|lccc|}
\hline Profit and Land Value Calculations & & & \\
\hline Discount Rate & $7.0 \%$ & $7.0 \%$ & $7.0 \%$ \\
Development Period (Years) & 2 & 2 & 2 \\
Profit Margin & $15 \%$ & $15 \%$ & $15 \%$ \\
\hline Profit & $\$ 5,022,343$ & $\$ 4,818,344$ & $\$ 4,410,344$ \\
Land Value (Present Value) & $-\$ 9,120,512$ & $-\$ 7,850,787$ & $-\$ 11,268,444$ \\
\hline Future Value & $-\$ 10,442,074$ & $-\$ 8,988,366$ & $-\$ 12,901,242$ \\
Future Value PSF & $-\$ 163$ & $-\$ 140$ & $-\$ 202$ \\
\hline Land Value PSF & $-\$ 456$ & $-\$ 393$ & $-\$ 563$ \\
\hline Buildable PSF & $-\$ 143$ & $-\$ 123$ & $-\$ 176$ \\
\hline
\end{tabular}


Table 13. Summary of development costs by station

\begin{tabular}{|l|c|c|c|}
\hline & Appleby & Ajax & Oshawa \\
\hline Building and Underground Parking & $\$ 13,759,986$ & $\$ 13,759,986$ & $\$ 13,759,986$ \\
\hline Surface Parking & $\$ 84,000$ & $\$ 84,000$ & $\$ 84,000$ \\
\hline Hard Costs & $\$ 13,843,986$ & $\$ 13,843,986$ & $\$ 13,843,986$ \\
\hline Financing & $\$ 16,924,742$ & $\$ 16,924,742$ & $\$ 16,924,742$ \\
\hline Base Soft Costs & $\$ 3,439,997$ & $\$ 3,439,997$ & $\$ 3,439,997$ \\
\hline Official Plan Amendment (OPA) & $\$ 29,335$ & $\$ 103,960$ & $\$ 21,016$ \\
\hline Zoning By-law Amendment & $\$ 59,143$ & $\$ 11,020$ & $*$ \\
\hline Development Charges & $\$ 1,270,162$ & $\$ 1,484,490$ & $\$ 1,927,300$ \\
\hline Density Bonusing & $\$ 11,500$ & $\$ 11,500$ & $\$ 11,500$ \\
\hline Parkland & $\$ 3,189,707$ & $\$ 331,006$ & $\$ 1,583,750$ \\
\hline Site Plan Control & $\$ 23,048$ & $\$ 63,698$ & $\$ 55,078$ \\
\hline Plan of Condominium Approval & $\$ 7,301$ & $\$ 12,510$ & $\$ 10,132$ \\
\hline Building Permit & $\$ 103,100$ & $\$ 65,404$ & $\$ 75,690$ \\
\hline Municipal Fees & $\$ 4,693,295$ & $\$ 2,083,588$ & $\$ 3,684,466$ \\
\hline Soft Costs & $\$ 8,133,292$ & $\$ 5,523,584$ & $\$ 7,124,463$ \\
\hline Total Development Costs & $\$ 38,902,020$ & $\$ 36,292,313$ & $\$ 37,893,191$ \\
\hline
\end{tabular}

* Combined with the OPA 


\section{$\underline{\text { References }}$}

Advisory Panel for the Coordinated Review of the Growth Plan, Greenbelt Plan, Oak Ridges Moraine Conservation Plan, and Niagara Escarpment Plan. (2015). Planning for Health, Prosperity and Growth in the Greater Golden Horseshoe: 2015 - 2041. Retrieved from: http://ossga.com/multimedia/0/planning_for_health_prosperity_and_growth__expert_panel_report.pdf

Altus Group. (2018). Construction Cost Guide. Retrieved from: http://www.altusgroup.com/news_insights/construction-cost-guide-2018

Amborksi, D. (2016). Affordable Housing and Land Supply Issues in the Greater Toronto Area (GTA). Centre for Urban Research and Land Development.

Beaumont, A. (2012). Barriers to mid-rise development in suburban communities in the Greater Toronto Area. Retrieved from: http://digital.library.ryerson.ca/islandora/object/RULA:1827/datastream/OBJ/download/Barriers_To _Mid-Rise_Development_in_Suburban_Communities_in_the_Greater_Toronto_Area.pdf

Blais, P. (2011). Perverse cities: hidden subsidies, wonky policy, and urban sprawl. UBC Press.

Blais, P. (2003). Smart Development for Smart Growth. Issues Papers No. 6. Neptis Foundation. Retrieved from:

http://www.neptis.org/sites/default/files/smart_growth_issue_papers_smart_development_and_smar t_growth/sm_dev_nip6_report.pdf

Belzer, D., \& Autler, G. (2002). Transit oriented development: moving from rhetoric to reality. Washington, DC: Brookings Institution Center on Urban and Metropolitan Policy.

Boarnet, M. G., \& Crane, R. (1998). Public finance and transit-oriented planning: New evidence from southern California. Journal of Planning Education and Research, 17(3), 206-219.

Bruegmann, R. (2006). Sprawl: A compact history. University of Chicago press.

Burda, C. (2017, December 4). 'Superlinx' is not the solution to the Toronto region's transit woes. Retrieved from: https://www.thestar.com/opinion/contributors/2017/12/04/superlinx-is-not-thesolution-to-the-toronto-regions-transit-woes.html

Brody, J. E. (2007, December 11). Mental reserves keep brain agile. The New York Times. Retrieved from http://www.nytimes.com

Calthorpe, P. (1993). The next American metropolis: Ecology, community, and the American dream. Princeton architectural press.

Canadian Centre for Economic Analysis. (2016). Regional Express Rail's Impact on Housing Affordability in the Greater Golden Horseshoe. Prepared for: Toronto Real Estate Board. Retrieved from: https://www.cancea.ca/sites/economic-analysis.ca/files/reports/TREB\%20Report\%20\%20final.pdf

Cervero, R,. Ferrell, C,. \& Murphy, S. (2002). Transit-oriented development and joint development in the United States: A literature review. Research Results Digest 52, Transit Cooperative Research Program, Transportation Research Board, Washington, DC 
City Building Institute. (2016). Suburbs on track: Building transit-friendly neighbourhoods outside the Toronto core. Retrieved from:

https://www.ryerson.ca/content/dam/citybuilding/pdfs/2016/REPORT-Suburbs\%20on\%20TrackSeptember\%207,\%202016.pdf

City of Burlington. (2018). Burlington Official Plan, Proposed. Retrieved from: https://www.burlington.ca/uploads/21480/Doc_636536031538947602.pdf

City of Burlington. (2017). Appleby GO Mobility Hub. Retrieved from: https://www.burlington.ca/en/your-city/resources/Grow-Bold/Mobility-Hubs/Appleby-GOMobility-Hub-Preferred-Concept.pdf

City of Burlington. (n.d.). Intensification. Retrieved from: https://www.burlington.ca/en/services-foryou/Intensification.asp?_mid_=1254

City of Toronto. (2017). 2016 Census: Population and Dwelling Counts. Retrieved from: https://www.toronto.ca/wp-content/uploads/2017/10/8f83-2016-Census-Backgrounder-PopulationDwellings.docx

City of Oshawa. (2017). Official Plan. Retrieved from: https://www.oshawa.ca/business-andinvestment/resources/City-of-Oshawa-Official-Plan.pdf

Clapson, M. (2003). Suburban century: Social change and urban growth in England and the USA. Berg.

Clayton, F. (2017). Overriding Preference for Ground Related Housing by GTA Millennials and Other Recent and Prospective Buyers. Centre for Urban Research and Land Development. Retrieved from: http://www.ryerson.ca/content/dam/cur/pdfs/Projects/CURReportGTAConsumerPreferences.pdf

CMHC. (n.d.). Residential Intensification Case Studies, Municipal Initiatives. Retrieved from: https://www.cmhc-schl.gc.ca/en/inpr/su/sucopl/upload/Exemption-from-Planning-andDevelopment-Fees-Ottawa-Ont.pdf

Dunphy, R. T., Cervero, R., Dock, F., Mc Avey, M., \& Porter, D. (2005). Developing Around Transit. Urban Land Institute.

Environmental Registry. (2017). Proposed regulation under the Planning Act related to inclusionary zoning. Retrieved from: https://www.ebr.gov.on.ca/ERS-WEB-

External/displaynoticecontent.do?noticeId=MTM0MDk1\&statusId=MjAzOTg2\&language $=e n$

Filion, P., \& McSpurren, K. (2007). Smart growth and development reality: The difficult coordination of land use and transport objectives. Urban Studies, 44(3), 501- 523.

Friedman, A. (2002). Planning the new suburbia: Flexibility by design. UBC Press.

GHK International, du Toit Allsopp Hillier, and AECOM. (2010). Growth Plan Implementation Study Final Report. Retrieved from:

https://www.ajax.ca/en/doingbusinessinajax/resources/IntensificationStrategy.pdf

Government of Ontario. Places to Grow Act, 2005, S.O. 2005, c. 13. Retrieved from: https://www.ontario.ca/laws/statute/05p13

Grant, J. L. (2009). Theory and practice in planning the suburbs: Challenges to implementing new urbanism, smart growth, and sustainability principles. Planning Theory \& Practice, 10(1), 11-33. 
Green, K. P., Herzog, I., \& Filipowicz, J. (2016). New Homes and Red Tape in Ontario: Residential Land-Use Regulation in the Greater Golden Horseshoe. Prepared for the Fraser Institute. Retrieved from: https://www.fraserinstitute.org/sites/default/files/new-homes-and-red-tape-in-ontarioresidential-land-use-regulation-post.pdf

Guthrie, A., \& Fan, Y. (2016). Developers' perspectives on transit-oriented development. Transport Policy, 51, 103-114.

Halton Region. (2016). Halton Region Official Plan. Retrieved from: http://www.halton.ca/cms/One.aspx?portalId=8310\&pageId=115808

Hess, D., \& Lombardi, P. (2004). Policy support for and barriers to transit-oriented development in the inner city: Literature review. Transportation Research Record: Journal of the Transportation Research Board, (1887), 26-33.

Legislative Assembly of Ontario. (n.d.) Bill 139, Building Better Communities and Conserving Watersheds Act, 2017. Retrieved from:

http://www.ontla.on.ca/web/bills/bills_detail.do?locale=en\&BillID=4936\&detailPage=bills_detail_s tatus

Lehrer, U., Keil, R., \& Kipfer, S. (2010). Reurbanization in Toronto: Condominium boom and social housing revitalization. disP-The Planning Review, 46(180), 81-90.

Lester, T. W., Kaza, N., \& Kirk, S. (2013). Making room for manufacturing: Understanding industrial land conversion in cities. Journal of the American Planning Association, 79(4), 295-313.

Loo, B. P., \& du Verle, F. (2017). Transit-oriented development in future cities: Towards a two-level sustainable mobility strategy. International Journal of Urban Sciences, 21(sup1), 54-67.

Lornic, J. (2017, November 12). Defanging the housing price monster. Retrieved from: https://www.theglobeandmail.com/real-estate/toronto/developers-eye-housing-projects-alongtoronto-transitroutes/article34884666/

Metrolinx. (2018). Draft 2041 Regional Transportation Plan for the Greater Toronto and Hamilton Area. Retrieved from: http://www.metrolinx.com/en/docs/pdf/board_agenda/20180308/20180308_BoardMtg_Draft_Final _2041_RTP_EN.pdf

Metrolinx. (2017). 2017-18 Metrolinx Business Plan. Retrieved from: http://www.metrolinx.com/en/docs/pdf/board_agenda/20170914/20170914_BoardMtg_BusinessPla n_Report_EN.pdf

Metrolinx. (2016a). GO Rail Station Access Plan. Retrieved from: http://www.metrolinx.com/en/regionalplanning/projectevaluation/studies/GO_Rail_Station_Access _Plan_EN.pdf

Metrolinx. (2016b). Context Paper on the Regional Economy, Demographic Outlook and Land Use. Prepared by Metrolinx, IBI and Hemson. Retrieved from: http://www.metrolinx.com/en/regionalplanning/rtp/technical/02_Context_Paper_Report_EN.pdf

Metrolinx. (2016c). Discussion Paper for the Next Regional Transportation Plan. Retrieved from: http://www.metrolinx.com/en/regionalplanning/rtp/RTP_Discussion_Paper_EN.pdf 
Metrolinx. (2015). GO Regional Express Rail Initial Business Case. Retrieved from: http://www.metrolinx.com/en/regionalplanning/projectevaluation/benefitscases/GO_RER_Initial_B usiness_Case_EN.pdf

Metrolinx. (2011). Mobility Hub Guidelines for the Greater Toronto and Hamilton Area. Retrieved from: http://www.metrolinx.com/en/regionalplanning/mobilityhubs/MobilityHubGuidelines.pdf

Metrolinx. (2008). The Big Move. Retrieved from:

http://www.metrolinx.com/thebigmove/Docs/big_move/TheBigMove_020109.pdf

Metrolinx Act (2006) S.O. 2006, c. 16

Ministry of Municipal Affairs. (2017). Growth Plan for the Greater Golden Horseshoe.

Ministry of Municipal Affairs. (2006). Growth Plan for the Greater Golden Horseshoe.

Ministry of Municipal Affairs and Housing. (2015). Our Region, Our Community, Our Home discussion document.

Ministry of Municipal Affairs and Housing. (2014). Provincial Policy Statement.

Ministry of Transportation. (2017). Ontario Making Transit More Convenient in Durham Region. Improvements to Oshawa GO Station Support Future 15-Minute Service. Retrieved from: https://news.ontario.ca/mto/en/2017/10/ontario-making-transit-more-convenient-in-durhamregion.html

Ministry of Transportation. (2012). Transit Supportive Guidelines. Retrieved from: http://www.mto.gov.on.ca/english/transit/pdfs/transit-supportive-guidelines.pdf

N. Barry Lyon Consultants Limited (NBLC). (2017). Burlington Mobility Hub Market Analysis. Prepared for Brook McIlroy.

N. Barry Lyon Consultants Limited (NBLC). (2016). Development Potential Adjacent to GO Rail Transit Stations. Prepared for Metrolinx.

Nelson, A. (2018). Planner's estimating guide: projecting land-use and facility needs. Routledge.

Nelson, A. C. (2017). Transit-Oriented Developments Make a Difference in Job Location. Fordham Urb. LJ, 44, 1079.

Nelson, A. (2004). Planner's estimating guide. Chicago. Planners Press/American Planning Association.

Neptis. (2015a). Growing Pains: Understanding the new reality of population and dwelling patterns in the Toronto and Vancouver regions. Retrieved from:

http://www.neptis.org/sites/default/files/growing_pains/growingpains_neptisreport_final.pdf

Neptis. (2015b). Planning for Prosperity. Retrieved from:

http://www.neptis.org/sites/default/files/planning4prosperity/p4p_neptis_report_final_web_0.pdf

Neptis. (2014). Governance: The third rail that powers integrated regional transit. Retrieved from: http://www.neptis.org/publications/governance-third-rail-powers-integrated-regional-transit\#_ftn7 
Neptis. (2008). Shaping the Toronto Region, Past, Present and Future. Retrieved from: http://www.neptis.org/sites/default/files/toronto_metropolitan_region_shaping_the_toronto_region/s haping_report_web_20080902_0.pdf

Niles, J., \& Nelson, D. (1999). Measuring the Success of Transit-Oriented Development. In Retail Market Dynamics and Other Key Determinants, Prepared for the American Planning Association National Planning Conference, Seattle, Washington, April (pp. 24-28).

Noland, R. B., Weiner, M. D., DiPetrillo, S., \& Kay, A. I. (2017). Attitudes towards transit-oriented development: Resident experiences and professional perspectives. Journal of Transport Geography, $60,130-140$.

Moos, M., \& Mendez, P. (2017). In Mapping Suburbanisms. In M. Moos, \& R. Walter-Joseph. (Eds.). Still Detached and Subdivided?: Suburban Ways of Living in 21st Century North America. (55106). Jovis Verlag GmbH.

Ontario Home Builders Association and Pembina Institute (2015). Make Way for Mid-Rise. Retrieved from: https://www.ohba.ca/make-way-mid-rise-build-homes-walkable-transit-connectedneighbourhoods/

Parker, T. (2002). Statewide transit-oriented development study: Factors for success in California. Business, Transportation and Housing Agency. Retrieved from: http://reconnectingamerica.org/assets/Uploads/bestpractice012.pdf

Peiser, R. B., \& Hamilton, D. (2012). Professional Real Estate Development: the ULI Guide to the Business. Urban Land Institute.

Pembina Institute. (2012). Live Where You Go, Encouraging location-efficient development in Ontario. Canadian Environmental Law Association, Ecojustice Canada, The Pembina Institute and Zizzo Allan Climate Law LLP. Retrieved from: http://www.pembina.org/pub/2354

Peng, Y. T., Li, Z. C., \& Choi, K. (2017). Transit-oriented development in an urban rail transportation corridor. Transportation Research Part B: Methodological, 103, 269-290.

Porter, D. (1997). TCRP Synthesis of Transit Practice 20: Transit Focused Development. Retrieved from: http://onlinepubs.trb.org/onlinepubs/tcrp/tsyn20.pdf

Regional Municipality of Durham. (2017). Durham Region Comments on Metrolinx Draft 2041 Regional Transportation Plan. Retrieved from: http://app.oshawa.ca/agendas/City_Council/2017/1218-2017/CORR_RF3.pdf

Region of Durham. (2017). Official Plan. Retrieved from: https://www.durham.ca/en/doingbusiness/resources/Documents/PlanningandDevelopment/Official-Plan/2017-Durham-RegionalOfficial-Plan-Consolidation.pdf

Renne, J. L. (2009). From transit-adjacent to transit-oriented development. Local Environment, 14(1), $1-15$.

Renne, J., \& Newman, P. (2002). Ideas in Motion: Facilitating the Financing and Development of 'Smart Growth'. Transportation Quarterly, 56(2)

RE/MAX. (2017). RE/MAX 2017 Spotlight on Luxury. Retrieved from: http://blog.remax.ca/remax2017-spotlight-luxury/ 
RBC-Pembina. (2014) Home Location Preference Survey Understanding where GTA residents prefer to live and commute. Retrieved from: http://www.rbc.com/community-sustainability/_assetscustom/pdf/RBC-Pembina-Home-Location-Preference-Survey.pdf

Ryerson City Building Institute. (2017). Governance Strategies to Achieve Transit-Oriented Development. Retrieved from: https://www.citybuildinginstitute.ca/2017/12/12/governancestrategies-to-achieve-transit-oriented-development/

Searle, G., \& Filion, P. (2011). Planning context and urban intensification outcomes: Sydney versus Toronto. Urban Studies, 48(7), 1419-1438.

Slack, E., \& Spicer, Z. (2014). City: Too Big, Too Small. Novae Res Urbis. Retrieved from: http://www.urbanstrategies.com/wp-content/uploads/2014/06/Novae-Res-Urbis.pdf

Sohoni, A. V., Thomas, M., \& Rao, K. K. (2017). Application of the concept of transit oriented development to a suburban neighborhood. Transportation Research Procedia, 25, 3224-3236.

Sotomayor, A. (2013). The Mid Rise Challenge: Tools for Incentivizing Private Developers. Retrieved from: http://digital.library.ryerson.ca/islandora/object/RULA\%3A5062/datastream/OBJ/download/The_m id_rise_challenge__tools_for_incentivizing_private_developers.pdf

Statistics Canada. (2016). Census of Population.

The Oshawa Express. (2018, March 1). Lakeshore East extension to break ground in 2019. Retrieved from: http://oshawaexpress.ca/lakeshore-east-extension-to-break-ground-in-2019/

Toronto Real Estate Board. (2018). Market Watch. Retrieved from: http://www.trebhome.com/market_news/market_watch/2018/mw1802.pdf

Toronto Region Board of Trade. (2017). Faster Commutes and Access to Transit Top Priorities for House-Hunting Young Professionals. Retrieved from:

https://www.bot.com/Portals/0/3of3_TRBT_HousingInfographic_FINAL.pdf

Toronto Region Board of Trade. (2017b). Superlinx: An Uploading Strategy for a Modern Provincial Transit Authority. Retrieved from:

https://www.bot.com/Portals/0/Board\%20of\%20Trade\%20Metrolinx\%20Submission_Superlinx\%2 0Strategy_Nov2017.pdf

Town of Ajax. (2016). Official Plan. Retrieved from:

https://www.ajax.ca/en/doingbusinessinajax/resources/Planning_Services/Ajax_Official_Plan_Cons olidation_Jan_15_2016.pdf

Waintrub, N., Greene, M., \& de Dios Ortúzar, J. (2016). Designing incentive packages for increased density and social inclusion in the neighbourhood of mass transit stations. Habitat International, 55, 133-147.

Watson \& Associates Economists Lt. (2014). Development Charges and Background Study. Retrieved from: https://www.burlington.ca/en/services-foryou/resources/Planning_and_Development/Development_Charges/2014_City_of_Burlington_Devel opment_Charges_Background_Study.pdf

Wickens, S. (2017, March 25). Toronto transit agency Metrolinx to take 'modest first step' into real estate. Retrieved from: https://www.theglobeandmail.com/news/toronto/toronto-transit-agencymetrolinx-to-take-modest-first-step-into-real-estate/article23194119/ 